\title{
RXR - centralny regulator wielu ścieżek sygnałowych w organizmie
}

Katarzyna Sołtys ${ }^{1}$, Bartosz Leszczyński², Andrzej Ożyhar ${ }^{1}$

${ }^{1}$ Katedra Biochemii, Biologii Molekularnej i Biotechnologii, Wydział Chemiczny, Politechnika Wrocławska, Wybrzeże Wyspiańskiego 27, 50-370, Wroctaw

2 e-mail: 234455@student.pwr.edu.pl

Abstrakt

Receptory jądrowe (NRs) tworzą największą nadrodzinę czynników transkrypcyjnych, które odgrywają ważną rolę w regulacji wielu procesów biologicznych. Receptor kwasu 9-cis-retinowego (RXR) wydaje się odgrywać szczególną rolę wśród tej grupy białek, a to ma związek z jego zdolnością do tworzenia dimerów z innymi NRs. Ze względu na kontrolę ekspresji wielu genów, RXR stanowi bardzo dobry cel licznych terapii. Nieprawidłowości w szlakach modulowanych przez RXR są powiązane m.in. z chorobami neurodegeneracyjnymi, otyłością, cukrzycą, a także nowotworami. Istnieje wiele związków mogących regulować aktywność transkrypcyjną RXR. Jednak obecnie dopuszczonych do użytku klinicznego jest tylko kilka z nich. Retinoidy normalizują wzrost i różnicowanie komórek skóry i błon śluzowych, ponadto działają immunomodulująco oraz przeciwzapalnie. Stąd są stosowane przede wszystkim w chorobach skóry i w terapii niektórych chorób nowotworowych. W artykule przedstawiono ogólne wiadomości na temat RXR, jego budowy, ligandów i mechanizmu działania oraz potencjalnej roli w terapii nowotworów i zespołu metabolicznego.

Słowa

kluczowe

receptory jądrowe • receptor kwasu 9-cis-retinowego • ligandy RXR・ zespół metaboliczny • terapia przeciwnowotworowa

Received: 26.07.2020, Accepted: 07.04.2021

Abstract

Nuclear receptors (NRs) are a superfamily of transcription factors that play an important role in regulating many biological processes. The retinoid X receptor ( $R X R$ ) is unique among NRs because it can form both homodimers and heterodimers with other representatives of the family. RXR modulates the expression of different genes and that is why it could be a good target for many therapies. Dysregulation of RXR signaling leads to various diseases, including neurodegenerative diseases, obesity, diabetes and cancer. Many molecules have been described as potential ligands for RXR. However, only a few of them are currently approved for clinical use. Retinoids play important role in regulation of skin cells growth and differentiation as well as have immunomodulatory and anti-inflammatory effects. Therefore they have found use in treatment of skin lesions and some types of cancers. This review summarizes general information about RXR, its structure, ligands and mechanism of action as well as its potential role in cancer therapy and metabolic syndrome.

\section{Keywords}

nuclear receptors $\bullet$ retinoid $X$ receptor $\cdot R X R$ ligands $•$ metabolic syndrome $\bullet$ cancer therapy

*Corresponding author e-mail: katarzyna.soltys@pwr.edu.pl

(a) Br:NC-ND 2021 Sottys et al. This work is licensed under the Creative Commons Attribution-NonCommercial-NoDerivs 4.0 License. 


\section{Wstęp}

Istotą funkcji czynników transkrypcyjnych (TFs, transcription factors) jest, specyficzna czasowo i tkankowo, regulacja poziomu syntezy transkryptów poszczególnych genów organizmu. Receptory jądrowe (NRs, nuclear receptors) tworzą szczególną i zarazem największą grupę TFs. Unikalną cechą odróżniającą NRs od innych TFs jest ich zdolność wiązania z małymi hydrofobowymi cząsteczkami zwanymi ligandami [1]. Ze względu na rodzaj wiązanej cząsteczki NRs można podzielić na dwie główne grupy (ryc. 1) [2]. Pierwszą stanowią receptory endokrynne (endocrine receptors), charakteryzujące się wysokim poziomem inicjacji transkrypcji docelowych genów (high transcriptional activity) i stałą dysocjacji (Kd) na poziomie nanomolarnym. W jej skład wchodzą zarówno receptory steroidowe (SHRs, steroid hormone receptors), jak $\mathrm{np}$.: receptor androgenowy (AR, androgen receptor), estrogenowy (ER, estrogen receptor), glukokortykoidowy (GR, glucocorticoid receptor), mineralokortykoidowy (MR, mineralocorticoid receptor), progesteronowy (PR, progesterone receptor) oraz receptory niesteroidowe, jak np.: receptor hormonów tarczycy (TR, thyroid hormone receptor), pochodnej witaminy D 1,25-dihydroksykalcyferolu (VDR, vitamin D receptor), kwasu całkowicie-trans-retinowego (RAR, retinoic acid receptor). Do drugiej grupy zaliczono tzw. receptory sieroce (orphan receptors). Ciągły rozwój wiedzy i najnowsze odkrycia na temat nadrodziny NRs pozwoliły na wyróżnienie wśród tej grupy tzw. receptorów sierocych prawdziwych (true orphan receptors) oraz adoptowanych (adopted orphan receptors). Do receptorów sierocych prawdziwych, dla których nie poznano dotąd ligandów, należą m.in.: DAX-1 (dosagesensitive sex reversal-adrenal hypoplasia congenita critical region on the $X$ chromosome, gene 1 ), COUP-TF (chicken ovalbumin upstream promoter transcription factor) oraz PNR (photoreceptor cell-specific nuclear receptor). Mianem receptorów sierocych adoptowanych określa się NRs, dla których ligandy zidentyfikowano w ostatnich latach. Charakteryzują się małym powinowactwem do liganda oraz niższym poziomem inicjacji transkrypcji genów w porównaniu do receptorów endokrynnych [2]. Należą do nich: receptor aktywowany proliferatorami peroksysomów (PPAR, peroxisome proliferator-activated receptor), receptor wiążący niektóre pochodne pregnanu (PXR, pregnane $X$ receptor) oraz receptor kwasu 9-cis-retinowego ( $R X R$, retinoid $X$ receptor).

RXR jest członkiem nadrodziny NRs, dla którego odkrycie liganda - kwasu 9-cis-retinowego (9cRA) dało początek nowej grupie - receptorów jądrowych adoptowanych. RXR zajmuje szczególne miejsce wśród pozostałych członków nadrodziny NRs. RXR pełni rolę wspólnego partnera (common partner) dla wielu białek z tej rodziny, przez co bierze udział w koordynacji różnych sygnałów hormonalnych i metabolicznych [4]. Ze względu na mnogość interakcji, RXR zdaje się być jednym z kluczowych receptorów odpowiedzialnych za utrzymanie homeostazy organizmu. Nieprawidłowości w szlakach

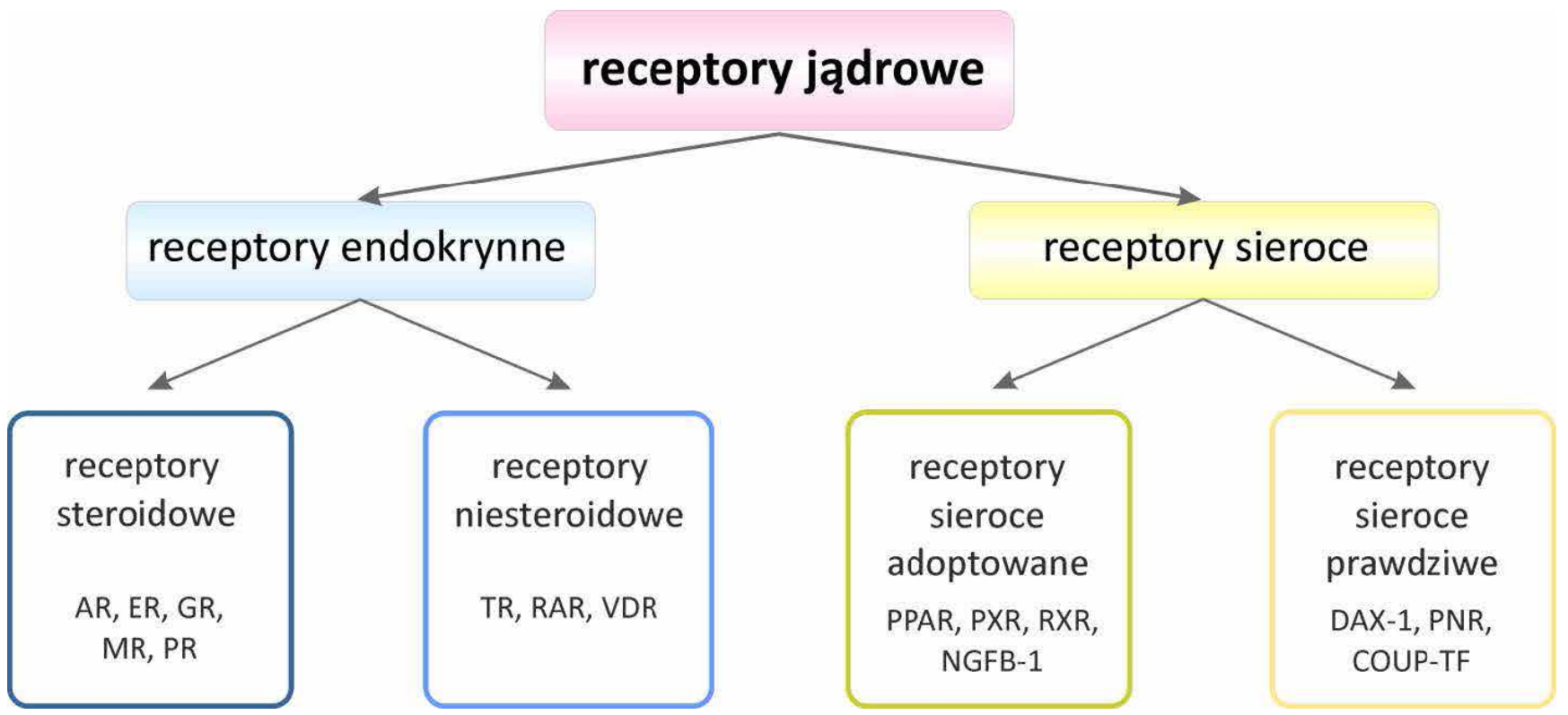

Rycina 1. Klasyfikacja receptorów jądrowych; schemat przedstawia podział receptorów jądrowych ze względu na rodzaj wiązanego liganda. Dwie główne grupy to receptory endokrynne oraz receptory sieroce. Receptory endokrynne można podzielić na receptory steroidowe i niesteroidowe, a receptory sieroce na adoptowane i prawdziwe. W ramkach podano przykłady receptorów należących do poszczególnych grup; wg [3] 
modulowanych przez NRs, a zwłaszcza związanych z aktywnością RXR, są powiązane m.in. z chorobami neurodegeneracyjnymi, niepłodnością, otyłością, cukrzycą, a także nowotworami [5]. W artykule przedstawiono obecny stan wiedzy na temat RXR.

\section{RXR - ogólna charakterystyka}

Receptor kwasu 9-cis-retinowego (RXR) zidentyfikowano i opisano po raz pierwszy w 1990 r. jako receptor sierocy [6]. Dopiero późniejsze badania wykazały, iż białko to wiąże retinoidy, w tym kwas 9-cis-retinowy (9cRA) i stąd też jego nazwa [7].

U ssaków występują trzy podtypy RXR (RXRa, RXRß oraz $\mathrm{RXRY}$ ) kodowane przez różne geny, które mają odmienny profil ekspresji [8]. RXRa występuje głównie w wątrobie, płucach, mięśniach, nerkach, jelicie oraz naskórku. RXRß jest obecny prawie we wszystkich tkankach, a RXRY głównie w mięśniach szkieletowych, mięśniu sercowym i mózgu [9]. Ponadto każdy z podtypów RXR posiada co najmniej dwie izoformy, będące wynikiem alternatywnego składania pierwotnego transkryptu lub wykorzystywania podczas transkrypcji alternatywnych promotorów [10]. Warianty RXR różnią się zazwyczaj w rejonie końca $\mathrm{N}$, fragmencie kluczowym dla regulacji tkankowoi komórkowo-specyficznej transkrypcji genów.

RXR kontroluje ekspresję genów tworząc homodimery/ homotetramery lub heterodimery z innymi NRs, przy czym każdy z trzech podtypów jest partnerem dla innych członków nadrodziny NRs [2, 11]. Wśród NRs dimeryzujących z RXR znalazły się zarówno receptory endokrynne (AR, TR, RAR, VDR), receptory związane $\mathrm{z}$ regulacją metabolizmu komórki (PPAR, PXR, LXR [liver $X$ receptor], FXR [farnesoid X receptor]), jak i receptory sieroce (Nurr1 [nuclear receptor related 1 protein], CAR [constitutive androstane receptor]). NRs tworzące heterodimery z RXR można podzielić na dwie funkcjonalne grupy. Do pierwszej z nich należą NRs zależne od liganda RXR (permissive), a do drugiej niezależne od liganda RXR (non-permissive) [12, 13]. Przykładami NRs pierwszej grupy są $\mathrm{m}$.in. receptory związane z metabolizmem energetycznym komórki (PPAR, LXR, PXR), charakteryzujące się niewielkim powinowactwem do liganda. Heterokompleksy RXR/PPAR, RXR/LXR i RXR/PXR mogą być aktywowane przez ligand $R X R$ lub jego partnera bądź też synergistycznie przez oba ligandy [14]. Do grupy receptorów zależnych od liganda RXR zalicza się również receptory sieroce - Nurr1 i COUP-TFs. Do grupy receptorów działających niezależnie od liganda RXR należą TR i VDR. Heterokompleksy RXR/ TR i RXR/VDR są aktywowane przez ligand partnera RXR [15]. Receptory te charakteryzują się dużym powinowactwem do liganda. RXR w tych kompleksach pełni rolę tzw. cichego partnera (silent partner). Jednak RXR zachowuje zdolność wiązania liganda i oddziaływania z koaktywatorami. Badania nad heterodimerami umożliwiły wyróżnienie jeszcze jednej grupy receptorów, które w pewnych warunkach są zależne od liganda RXR (conditional permissive partners) [12, 13]; do tej grupy zaliczono RAR [16]. Związanie liganda RXR nie powoduje aktywacji heterodimeru RXR/RAR, a związanie liganda partnera tylko częściową aktywację kompleksu. Do osiągnięcia maksymalnej aktywności transkrypcyjnej potrzebny jest również ligand RXR. W pewnych typach komórek (np. komórki nowotworowe jelita grubego) RXR/ VDR również wykazuje podobny sposób działania [3].

W komórce RXR pozostaje w dynamicznej równowadze między heterodimerami a homodimerami [17] i homotetramerami [18]. Rola homodimerów RXR in vivo została opisana stosunkowo niedawno. Wskazano, że aktywowane ligandem homodimery RXRa wiążą się bezpośrednio do regionów promotorowych genu inhibitora kinaz zależnych od cyklin p21 i odpowiadają za wzrost jego ekspresji i do zatrzymania wzrostu komórek nowotworowych [19]. Homodimery RXR biorą również udział w regulacji odpowiedzi wrodzonej przez wpływ na ekspresję chemokin Cd6 i Ccl9 w makrofagach [20]. Natomiast homotetramery RXR powstają w odpowiednim stężeniu białka w komórce oraz przy braku liganda [18]. W zależności od genu, homotetramery mogą działać jako aktywator lub represor transkrypcji [13]. Istotna właściwością homotetramerów RXR jest ich zdolność do zmiany architektury DNA. Wykazano, że jeżeli w sekwencji promotorowej, w odpowiedniej odległości od siebie, występują dwie specyficzne sekwencje regulatorowe (HREs, hormonresponse elements), to wiążące się do nich dimery $R X R$ mogą ze sobą asocjować tworząc tetramer i tym samym powodować powstanie pętli DNA [13]. Stwarza to możliwość dodatkowego sposobu kontroli transkrypcji przez rearanżację przestrzenną DNA, która zależy od stanu oligomerycznego receptora kontrolowanego przez ligand. Wytworzenie pętli DNA może zbliżyć do siebie odległe HREs umożliwiając oddziaływanie białek regulatorowych. Tetrametry RXR (podtypy a i y) są zaangażowane w regulację transkrypcji genu białka CRBPII (cellular retinol-binding protein II) przez oddziaływanie z HREs w obrębie promotora [21].

Analizy genetyczne wykazały, że RXR jest zaangażowany w wiele procesów związanych z rozwojem i utrzymaniem homeostazy. W celu określenia roli poszczególnych podtypów RXR w okresie płodowym przeprowadzono eksperymenty z wykorzystaniem modeli mysich [22]. Wykazano, że głównym podtypem na tym etapie rozwoju jest $m R X R a$, dla którego knock out genu okazał się letalny, co miało związek z licznymi wadami w mięśniu sercowym. Ponadto płody miały uszkodzony narząd wzroku. W przypadku inaktywacji genu podtypu $m R X R \beta$ wskaźnik przeżycia był na poziomie 50\%. Natomiast 
mutanty podtypu $m R X R Y$ charakteryzowały się wyższym poziomem hormonu stymulującego tarczycę i tyroksyny oraz miały zwiększone tempo metabolizmu w porównaniu ze zwierzętami typu dzikiego. Podstawową rolę w zrozumieniu złożoności układu RXR odegrały badania z użyciem technik: EMSA (electrophoretic mobility shift assay) czy kotransfekcje wybranych linii komórkowych. Jednak metody te pozwalają jedynie na analizę ekspresji poszczególnych genów czy pojedynczych sekwencji regulatorowych. Obecnie w celu określenia genów znajdujących się pod kontrolą RXR oraz procesów, w których uczestniczą, wykorzystuje się mikromacierze DNA oraz metodę RT-PCR (reverse transcription polymerase chain reaction). Techniki te pozwolity na zidentyfikowanie m.in. genów ważnych dla syntezy kwasów żółciowych znajdujących się pod kontrolą heterodimeru RAR/ RXR, w tym genu CYP7A1 [23] oraz genów związanych $\mathrm{z}$ regulacją metabolizmu kwasów tłuszczowych i utrzymaniem homeostazy glukozowej, których ekspresja jest zależna od heterodimerów RXR/LXR (SREBP1C, SCD1, FASN) oraz RXR/PPAR $\alpha$ (ABCB4, ApoAll, ACOX1) [24]. Pozwoliły również na scharakteryzowanie zestawów genów znajdujących się pod kontrolą ligandów RXR (LG100268 - agonisty RXR i kwasu 9-cis-retinowego) oraz jego partnerów (LXR, PPAR, RAR i VDR) w ludzkich komórkach dendrytycznych wywodzących się z monocytów (Mo-DCs, human monocytederived dendritic cells) [25]. Zaobserwowano, że ligandy RXR wpływają głównie na poziom ekspresji genów będących pod kontrolą heterodimerów RXR/LXR i RXR/ PPAR. Natomiast wywierają niewielki wpływ na ekspresję genów regulowanych przez heterodimery RXR/VDR i RXR/ RAR. Zastosowanie mikromacierzy DNA umożliwiło również poszukiwanie markerów chorób nowotworowych, w tym raka piersi [26]. W ludzkich komórkach nabłonkowych sutka (HMECs, human mammary epithelial cells) zidentyfikowano 353 geny znajdujące się pod kontrolą beksarotenu, ligadna RXR. Wśród nich znalazły się geny kodujące takie białka jak: cyclina D1, COX-2 (cyclooxygenase-2), IGFBP-6 (insulinlike growth factor-binding protein 6) [26]. Przeprowadzone badania potwierdziły również chemioprewencyjne właściwości beksarotenu. Mikromacierze DNA pozwalają również na analizę nowych związków (np. analogów beksarotenu) mogących mieć znaczenie terapeutyczne [12].

\section{Budowa RXR}

Jak większość NRs, RXR ma budowę modułową, na którą składa się sześć powiązanych funkcjonalnie regionów oznaczonych literami od A do F (ryc. 2A). Na końcu N RXR znajduje się region $A B-w$ tej grupie receptorów wskazanie granicy miedzy regionem $A$ i regionem $B$ nie jest możliwe (ryc. 2A i 2C) [11, 27]. Region AB jest najmniej zachowanym w toku ewolucji fragmentem NRs i wykazuje najmniejszy stopień podobieństwa między poszczególnymi członkami nadrodziny. Różnice wynikają nie tylko z odmiennej sekwencji aminokwasowej, ale także ze znacznej różnicy w długości. Taka różnorodność $w$ obrębie regionu $A B$ pozwoliła na wyróżnienie trzech podtypów RXR ( $\alpha, \beta$ i $ү$ ) oraz co najmniej dwóch izoform dla każdego z podtypów receptora [28]. Ma to odzwierciedlenie w aktywności transkrypcyjnej podtypów/ izoform RXR, zależnej od typu komórki oraz sekwencji promotorowej, ponieważ $w$ regionie $A B$ jest umiejscowiona sekwencja odpowiedzialna za autonomiczną, tj. niezależną od liganda, aktywację transkrypcji (AF1; activation function 1). Sekwencja AF1 bierze udział $w$ regulacji transkrypcji głównie przez oddziaływanie białko-białko z koregulatorami i TFs [29, 30], jednak podstawy tych oddziaływań nie są dobrze poznane. Badania nad regionem $A B$ różnych NRs wykazały, że w roztworze charakteryzuje się on brakiem stabilnej struktury drugo- i trzeciorzędowej, przez co może przyjmować różne konformacje [31]. Przypuszcza się, iż takie nieuporządkowanie $w$ obrębie regionu $A B$ umożliwia oddziaływanie $\mathrm{z}$ większą grupą białek, niż w przypadku istnienia zdefiniowanej struktury wyższego rzędu. Należy również podkreślić, że oddziaływanie regionu $A B$ $z$ koregulatorami jest selektywne i region ten nie oddziałuje w sposób przypadkowy z białkami. Przyjęcie konkretnej konformacji regionu AB zależy od danego typu komórki oraz od interakcji wewnątrzcząsteczkowych i międzycząsteczkowych, $w$ jakie region $A B$ jest zaangażowany, a od formy złożonego kompleksu zależy ostateczna odpowiedź [32]. Związki, które wiążą się z regionem $A B(A F 1)$ można by wykorzystać w terapii opartej na NRs. Wykazano, że pochodna bisfenolu A wchodzi $w$ interakcję $z$ AF1 receptora androgenowego (AR) i zakłóca wiązanie koaktywatorów z obszarem AF1, a następnie ekspresję docelowego genu znajdującego się pod kontrolą AR [33].

Region $A B$ ze względu na swój charakter jest częstym celem różnych modyfikacji potranslacyjnych (PTMs, posttranslational modifications), takich jak: fosforylacja, metylacja, acetylacja, ubikwitynylacja czy sumoilacja, które wpływają zarówno na strukturę jak i funkcję NR. Obecnie strukturalne i funkcjonalne następstwa modyfikacji w obrębie regionu $A B$ są przedmiotem intensywnych badań [34]. PTM mającą duży wpływ na aktywność transkrypcyjną RXR jest fosforylacja. Wpływ tej modyfikacji został zbadany dla dwóch podtypów RXRa i RXRY [35, 36]. Kinazy odpowiedzialne za modyfikacje regionu $A B \quad R X R$ należą do grupy kinaz serynowotreoninowych. Skutek modyfikacji zależy od typu komórki, podtypu receptora oraz warunków eksperymentalnych [29]. Wskazano, że RXRa jest modyfikowany konstytutywnie na S22 przez kinazę należącą do rodziny CDKs (cyclin-dependent kinases) w komórkach COS-1 [37]. Rola tej modyfikacji została szerzej zbadana w mysiej linii komórkowej F9 [38]. 
Udowodniono, że modyfikacja ta jest istotna dla ekspresji wybranych genów znajdujących się pod kontrolą retinoidów oraz że aktywność transkrypcyjna RXR jest regulowana przez zmianę powinowactwa do koaktywatorów. Fosforylacja S22 jest również niezbędna do odpowiedzi antyproliferacyjnej komórek na retinoidy. Modyfikacja RXR obniżała poziom białek p21 $1^{\mathrm{CIP}}$ i p27 ${ }^{\mathrm{KIP}}$, które są zaangażowane w kontrolę cyklu komórkowego. Zauważono również, że liczba miejsc fosforylacji w obrębie regionu $A B$ może zależeć od warunków. W wyniku działania czynników stresowych na komórki COS-1 obserwowano zwiększenie liczby miejsc fosforylacji w regionie $A B$ [37]. Pod wpływem działania promieniowania ultrafioletowego region $A B R X R \alpha$ ulegał modyfikacji na resztach S61, S75 i T87 w wyniku działania kinaz JNKs (c-Jun $\mathrm{N}$-terminal kinases). Wskazano, że hiperfosforylacja nie ma wpływu na aktywność transkrypcyjną homodimerów RXR. Jednak przypuszcza się, że może wpływać na stabilność RXR i chronić receptor przed degradacją lub indukować apoptozę [37]. Istotną modyfikacją aktywności transkrypcyjnej RXR jest również sumoilacja [39]. Przyłączenie białka SUMO (small ubiquitin-related modifier 1 ) do reszty K108 (w obrębie motywu IKPP) znajdującej się w regionie AB i obejmującej obszar AF1, hamuje aktywność transkrypcyjną RXRa. Natomiast usunięcie tej modyfikacji, w wyniku działania proteazy SUSP1 (SUMO-1-specific protease), zwiększa aktywność transkrypcyjną zarówno RXR, jak i heterodimerów z RARa i PPARy [39].

Nowo odkrytą rolą regionu $A B R X R$ jest jego zdolność do promowania separacji faz typu ciecz-ciecz (LLPS, liquidliquid phase separation) [40]. Jest to proces, w którym z jednorodnej fazy ciekłej zawierającej makrocząsteczki (białka, kwasy nukleinowe) tworzą się dwie oddzielne fazy, jedna bogata w makrocząsteczki (dense phase) oraz druga, w której ich stężenie jest znacznie mniejsze (dilute phase) [41]. Zjawisko to odpowiada m.in., za tworzenie w komórkach tzw. bezbłonowych organelli (MLOs, membraneless organelles), takich jak np. jąderko, plamki jądrowe (nuclear speckles), ciałka P (P-bodies) i ciałka stresowe (stress granules). Rosnąca liczba publikacji wskazuje, że LLPS stanowi niezwykle istotny mechanizm organizacji przestrzeni wewnątrzkomórkowej. Szacuje się, że ponad 30\% ludzkiego proteomu jest związane z MLOs [42]. Uważa się, że LLPS leży u podstaw wielu procesów biologicznych, takich jak odpowiedź na stres, regulacja transkrypcji, metabolizm RNA, transport jądrowo-cytoplazmatyczny czy przekazywanie sygnałów [43]. Zaburzenia LLPS w komórkach i organizmach towarzyszą wielu chorobom. Do najczęściej wymienianych należą nowotwory, zaburzenia neurologiczne, takie jak stwardnienie zanikowe boczne (ALS, amyotrophic lateral sclerosis) i zanik mięśni (muscular atrophies) [42]. W przypadku TFs głównym elementem odpowiedzialnym za LLPS wydają się domeny aktywacyjne (ADs, activation domains) [44]. Dla wybranych
TFs wskazano, że to właśnie ADs poprzez LLPS odpowiadają za oddziaływanie z kompleksami pośredniczącymi (mediator complexes). Stąd LLPS wydaje się istotnym elementem aktywacji transkrypcji. Dla regionu $\mathrm{AB} h \mathrm{RXR}$ wykazano, że jest zdolny promować LLPS [40]. Jednak konieczne są dalsze prace mające na celu zbadanie tego zjawiska i jego wpływu na ekspresję genów.

Region C jest najbardziej zachowanym w toku ewolucji fragmentem NRs (ryc. 2). Wraz $z$ końcem $N$ regionu $D$, tzw. przedłużeniem końca C (CTE, C-terminal extension), tworzy domenę wiążącą DNA (DBD), zaangażowaną bezpośrednio w rozpoznawanie i wiązanie ze specyficznymi sekwencjami regulatorowymi na DNA (HREs) [45]. Rdzeń DBD składa się z około 66 reszt aminokwasowych tworzących globularną domenę, której charakterystyczną cechą jest występowanie dwóch motywów palca cynkowego, gdzie cztery reszty cysteinylowe chelatują $\mathrm{Zn}^{2+}$. Ich rolą jest stabilizacja struktury składającej się $z$ dwóch $\alpha$-helis ułożonych prostopadle względem siebie, odpowiedzialnych za kontakt i rozpoznanie sekwencji DNA [45]. Na podstawie eksperymentów mutagenezy w regionie $\mathrm{C}$ wyróżniono kasetę $P$ (proximal box) oraz kasetę D (distal box) (ryc. 2B) [46]. Kaseta $P$, obejmująca aminokwasy należące do pierwszego modułu cynkowego, jest częścią helisy I, odpowiadającej za rozpoznanie specyficznych sekwencji DNA. Kaseta D występuje w N-końcowej części drugiego modułu cynkowego i jest związana z zależną od DNA dimeryzacją NRs. Do DBD zaliczany jest również koniec aminowy regionu $D$, tzw. CTE. CTE odgrywa ważną rolę w oddziaływaniach typu białko-DNA oraz białko-białko. W przeciwieństwie do pozostałej części DBD nie jest to sekwencja konserwowana i przyjmuje różne motywy strukturalne. W obrębie CTE wyróżniono dwie kasety: A i T (ryc. 2B). Kasetę $\mathrm{T}$ zidentyfikowano po raz pierwszy w RXRß jako sekwencję niezbędną w dimeryzacji [47], a następnie potwierdzono jej rolę w tworzeniu płaszczyzny homo- i heterodimeryzacyjnej z RAR [48, 49]. Kaseta A jest odpowiedzialna za rozpoznawanie dodatkowych sekwencji DNA, poza tymi rozpoznawanymi przez moduły cynkowe [47]. W DBD RXR zlokalizowano również dwie ważne sekwencje decydujące o dystrybucji receptora w komórce. WDBD znajduje się zarówno sygnał odpowiedzialny za translokację receptora do jądra komórkowego (NLS, nuclear localization signal) [27], jak również sygnał eksportu jądrowego (NES, nuclear export signal) [50]. RXR ma lokalizację głównie jądrową [51], jednak w nieobecności liganda RXR przemieszcza się między jądrem a cytoplazmą. W cytoplazmie RXR może tworzyć kompleksy z innymi NRs (np. PXR, CAR, VDR i TR) i po pojawieniu się liganda $R X R$ wpływać na zmianę lokalizacji heterodimeru z cytoplazmatycznej na jądrową [52]. Jest to kolejny ważny aspekt mechanizmu regulacji NRs z udziałem $R X R$.

Region D, zwany również regionem zawiasowym (hinge region) jest odcinkiem łączącym DBD z domeną wiążącą 
A

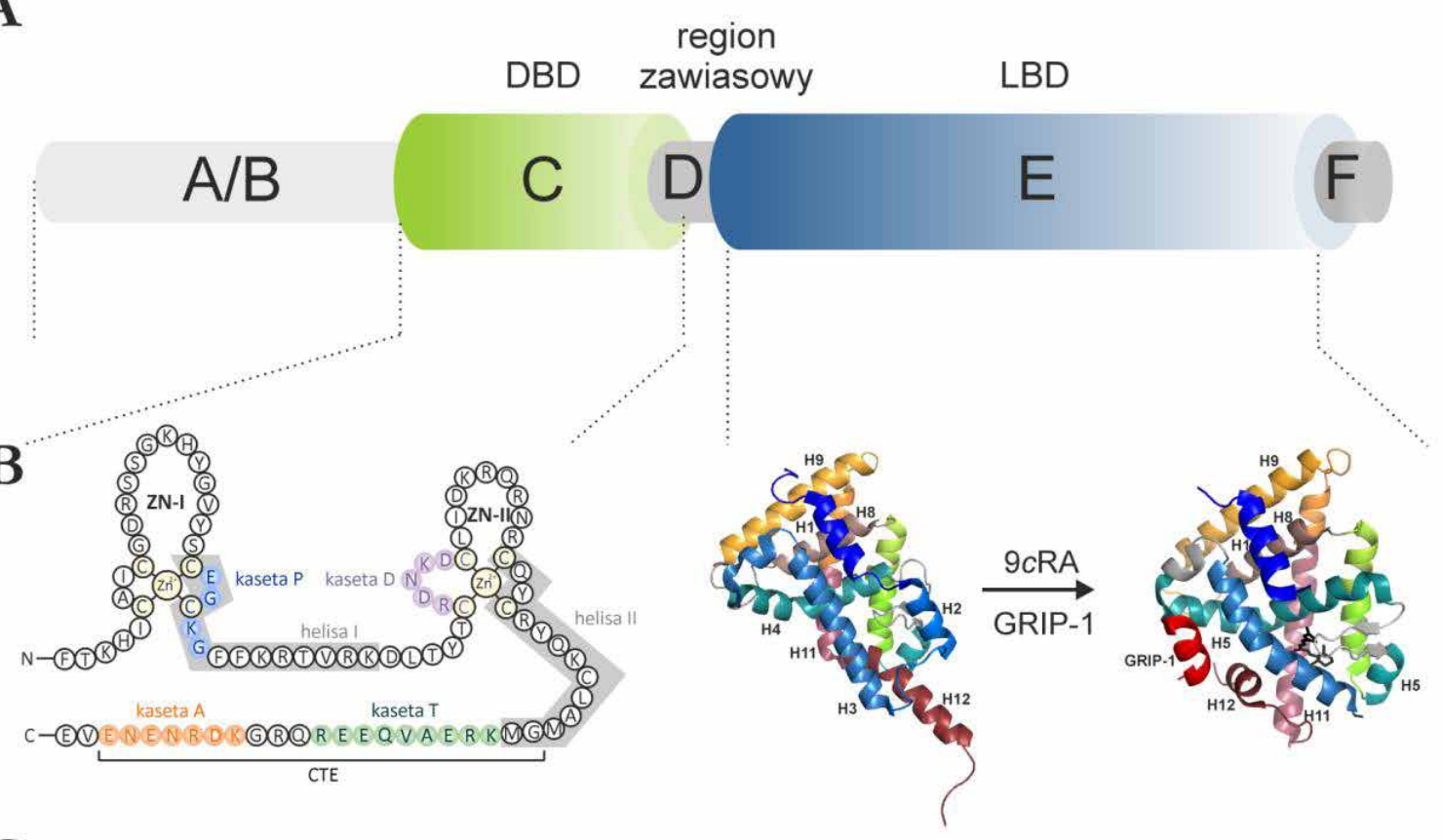

C

\begin{tabular}{|c|c|c|c|}
\hline region $A / B$ & DBD & region $\mathrm{D}$ & LBD \\
\hline $\begin{array}{l}\text { * region specyficzny } \\
\text { dla danego podtypu/ } \\
\text { izoformy; } \\
\text { * specyficzność } \\
\text { komórkowa/promotorowa; } \\
\text { "AF1; } \\
\text { * oddziaływanie } \\
\text { z koregulatorami; } \\
\text { * region wykazujący } \\
\text { inherentne } \\
\text { nieuporządkowanie } \\
\text { strukturalne (IDR); } \\
\text { * PTMs; } \\
\text { * LLPS; }\end{array}$ & $\begin{array}{l}\text { * wiązanie DNA; } \\
\text { * wysoce zachowana } \\
\text { w toku ewolucji; } \\
\text { * dimeryzacja (słaba, } \\
\text { indukowana przez DNA); } \\
\text { * NES/NLS; }\end{array}$ & $\begin{array}{l}\text { * region wykazujący } \\
\text { inherentne } \\
\text { nieuporządkowanie } \\
\text { strukturalne (IDR); } \\
\text { * rejon słabo zachowany } \\
\text { w toku ewolucji; }\end{array}$ & $\begin{array}{l}\text { * wiązanie liganda; } \\
\text { *AF2; } \\
\text { * dobrze zachowana w toku } \\
\text { ewolucji; } \\
\text { * wysoce ustrukturyzowana; } \\
\text { * dimeryzacja niezależna } \\
\text { od DNA; } \\
\text { * oddziaływanie } \\
\text { z koregulatorami; } \\
\text { * NES; } \\
\text { * PTMs; }\end{array}$ \\
\hline
\end{tabular}

Rycina 2. Schemat strukturalnej i funkcjonalnej organizacji RXR; A - RXR jest zbudowany z sześciu regionów oznaczonych A-F. B. Istnienie struktur wyższego rzędu oraz kryteria funkcjonalne przyczyniły się do wyróżnienia domen: domeny wiążącej DNA (DBD) i domeny wiążącej ligand (LBD). Schemat po lewej stronie przedstawia sekwencję aminokwasową DBD podtypu $h R X R a$, obejmującą region $C$ oraz koniec N regionu D, tzw. C-końcowe wydłużenie (CTE). Kolorem żółtym zaznaczono reszty cysteinylowe koordynujące dwa jony cynku, a kolorem szarym reszty aminokwasowe, które wchodzą w skład dwóch a-helis. Zaznaczono również reszty obejmujące kasety $P$, D, T i A zaangażowane w oddziaływanie z DNA i dimeryzacje. Schemat po prawej stronie przedstawia struktury krystaliczne $h R X R \alpha$ LBD niezwiązanej z ligandem (PDB, 6HN6) oraz po związaniu liganda (9cRA) i koaktywatora GRIP-1 (ang. GR-interacting protein 1) (PDB, 3OAP). Obie struktury różnią się istotnie, głównie pod względem innego położenia helisy H12. C. Krótka charakterystyka funkcjonalna dla poszczególnych regionów/ domen RXR; wg [53, 54, 55, 56]

ligand (LBD, ligand-binding domain) (ryc. 2Ai 2C) [11, 27]. Jest to drugi region w RXR, w którym występują znaczne różnice w sekwencji aminokwasowej między podtypami/izoformami receptora. Region D wykazuje inherentne nieuporządkowanie strukturalne (IDR, intrinsically disordered region), umożliwia rotację DBD względem LBD, co pozwala RXR na dimeryzację z różnymi partnerami oraz na oddziaływanie z wieloma elementami regulatorowymi.

Region E (LBD) jest drugim, po regionie C, elementem budowy NRs w znacznym stopniu zachowanym w toku ewolucji pod względem sekwencji aminokwasowej (ryc. 2). Region E pośredniczy głównie w procesach indukowanych przyłączeniem liganda [57]. Przyjmuje się, że region ten jest 
najbardziej złożonym fragmentem receptora pod względem funkcjonalnym. Zawiera sekwencję odpowiedzialną za zależną od liganda aktywację transkrypcji (AF2, activation function 2), ponadto jest zaangażowany $w$ niezależną od DNA dimeryzację, oddziaływanie $z$ koregulatorami oraz często w nieobecności liganda pośredniczy w represji transkrypcji [35]. Spośród wszystkich regionów RXR, region E (LBD) jest przedmiotem największej liczby publikacji. Świadczy o tym liczba rozwiązanych struktur krystalicznych, które przedstawiają LBD zarówno w nieobecności liganda (tzw. apo-LBD), jak i po związaniu liganda (holo-LBD) oraz w kompleksach z partnerami czy w obecności fragmentów koaktywatorów. Na LBD RXR składa się dwanaście helis a $(\mathrm{H} 1-\mathrm{H} 12)$ i struktura $\beta$ (ryc. 2B) [58]. Trzy zestawy helis tworzą hydrofobową kieszeń, miejsce wiązania liganda (LBP, ligand binding pocket). LBP RXR ma kształt litery $L i$ jest stosunkowo nieduża (około $500 \AA^{3}$ ), a ligandy zajmują większą część LBP, np. 9cRA zajmuje około $75 \%$, a kwas dokozaheksaenowy (DHA, docosahexaenoic acid) $80 \%$ dostępnej przestrzeni [35]. LBP RXRs jest silnie zachowana w toku ewolucji, co znacznie utrudnia zaprojektowanie i znalezienie liganda specyficznie oddziałującego $z$ danym podtypem/izoformą RXR [59, 60]. Porównując struktury domen RXRs bez liganda (apo-LBD) i z ligandem (holo-LBD) zauważono znaczne zmiany konformacyjne, jakie wywołuje jego związanie, z których najistotniejszą jest przemieszczenie helisy $\mathrm{H} 12$ w stronę wnętrza LBD (ryc. 2B). W holo-LBD helisa H12 tworzy swego rodzaju pokrywę zamykającą ligand w kieszeni. W wyniku zmian konformacyjnych utworzona zostaje domena aktywacyjna (AF2), z którą mogą się wiązać koaktywatory, co prowadzi do aktywacji transkrypcji [61]. Pozycja helisy H12RXR nie zawsze jest taka sama i może się zmieniać w zależności od partnera RXR [62]. Zaobserwowano, że wiązanie liganda przez jeden NR może wpływać na oddziaływanie między koregulatorami a partnerem dimeryzacyjnym $\mathrm{w}$ obrębie kompleksu [63]. Helisa H12 RXR pozostaje w aktywnej konformacji $\mathrm{i}$ jej położenie $\mathrm{w}$ strukturze trzeciorzędowej jest stabilizowane przez oddziaływanie z holo-LBD PPAR, należącym do grupy receptorów zależnych od liganda RXR. Natomiast tworzenie dimeru $z$ TR, będącego receptorem działającym niezależnie od liganda RXR, prowadzi do zmian konformacyjnych w LBD RXR, co utrudnia wiązanie liganda. Opisane zjawisko allosterii związane z LBD jest szczególnie istotne w kontekście całego receptora. Kontrola allosteryczna funkcji NRs jest modulowana przez liczne czynniki omówione w artykule, takie jak: specyficzne komórkowo koregulatory, PTMs, HRE, partnerzy NRs. Allosteria jest ważnym sposobem regulacji NRs, umożliwiającym stopniowe przekazywanie sygnału.

Ważnym czynnikiem mogącym regulować aktywność LBD są PTMs, a zwłaszcza fosforylacja [29]. Kinaza aktywująca MAPK (mitogen-activated protein kinase) (MKK4/SEK1) odpowiada za modyfikacje reszt Y249 i Y397, co jest związane z hamowaniem aktywności transkrypcyjnej $h \mathrm{RXRa}$ [64]. Natomiast indukowana stresem fosforylacja reszty S265 $m R X R a$ obniża aktywność transkrypcyjną heterodimerów RAR/RXR [35, 65]. Zaproponowano, że modyfikacja tej reszty odpowiada za zmiany konformacyjne w obrębie LBD i zakłóca interakcje z koregulatorami [59]. Natomiast fosforylacja reszty S260 $h$ RXRa przez MAPKs, jest ściśle związana ze zwiększoną stabilnością receptora i mniejszą podatnością na degradację, niewielką aktywnością transaktywacyjną jak i promowaniem wzrostu komórek nowotworowych [66]. Fosforylacja reszty S260 $h \mathrm{RXR} \alpha$ jest odpowiedzialna również za obniżenie aktywności transkrypcyjnej RXR/VDR [67].

W LBD RXR jest umiejscowiony kolejny sygnał NES [65]; sekwencja ta jest aktywna przy braku liganda. Sygnał NES RXR jest wymagany do eksportu jądrowego receptora sierocego NGFI-B (nerve growth factor-induced protein B) (RXR/NGFI-B) [51]. W oddziaływanie między białkami są zaangażowane DBD obu receptorów. W chwili pojawienia się liganda, sygnał NES RXR zostaje zablokowany, zmienia się płaszczyzna oddziaływania - białka oddziałują przez LBD, a kompleks zostaje przeniesiony do jądra [65].

Region $\mathrm{F}$ pozostaje nadal najmniej poznany pod względem funkcjonalnym i strukturalnym (ryc. 2A); nie występuje u wszystkich członków nadrodziny NRs. Do regionu F często zalicza się reszty znajdujące się na końcu karboksylowym receptora, nie występujące w strukturze krystalicznej [58]. W przypadku poszczególnych podtypów/izoform RXR, region ten jest $w$ dużym stopniu zróżnicowany pod względem sekwencji i obejmuje jedynie kilka reszt aminokwasowych. Przypuszcza się, że może mieć znaczenie dla stabilności RXR oraz wpływać na jego aktywność transkrypcyjną [9].

\section{Mechanizm działania RXR}

Regulacja transkrypcji zudziałem RXR wymaga specyficznego oddziaływania receptora z sekwencjami regulatorowymi na DNA (HRE), umiejscowionymi w rejonach promotorowych docelowych genów [58]. Sekwencje te wykazują wiele istotnych cech strukturalnych wpływających na specyficzność odpowiedzi hormonalnej. Sekwencje DNA rozpoznawane przez dimery RXR składają się $z$ dwóch powtórzonych kopii pochodnych sekwencji AGGTCA, oddzielonych krótkim fragmentem o długości 1-5 nukleotydów (DR1-DR5) [68]. Homodimery RXR-RXR i heterodimery RXR-PPAR, RAR/ RXR mogą się wiązać z motywem DR1, RXR/RAR z DR2 i DR5, RXR-VDR z DR3, natomiast RXR/TR z DR4. Zarówno sama sekwencja AGGTCA, jej orientacja, sekwencja łącznika, jak również sekwencje otaczające motyw pełnią ważną rolę, gdyż determinują specyficzność wiązania dimerów. Ponieważ RXR jest obligatoryjnym partnerem dla dużej grupy NRs, 
potencjalna liczba genów znajdująca się pod ich kontrolą jest olbrzymia.

NRs regulują poziom transkrypcji przez wpływ na:

- zmianę stopnia upakowania chromatyny,

- powstawanie i aktywność kompleksów inicjacyjnych i elongacyjnych [58].

Uważa się, że w pełnienie powyższych funkcji zaangażowane są domeny transaktywacyjne: AF1 (niezależna od obecności liganda) i AF2 (zależna od obecności liganda), które pośredniczą $w$ oddziaływaniach $\mathrm{z}$ podstawową maszynerią transkrypcyjną oraz $\mathrm{z}$ wieloma białkami zwanymi koregulatorami. Wśród koregulatorów znajdują się białka pełniące funkcje zarówno koaktywatorów, jak i korepresorów transkrypcji [69]. W nieobecności liganda korepresory oddziałują z LBD RXR, który jest związany $z$ partnerem na HRE, co powoduje hamowanie podstawowej aktywności transkrypcyjnej (ryc. 3A) [70]. Zawierają charakterystyczny motyw strukturalny LXXH/IIXXXI/L zwany kasetą CoRNR (corepressor nuclear receptor box). Najlepiej scharakteryzowanymi przedstawicielami korepresorów są kompleksy NCoR (nuclear receptor corepressor) i SMRT (silencing mediator of retinoid and thyroid hormone receptors). Kompleksy te mają aktywność deacetylazy histonów (HDAC, histone deacetylase), która usuwa grupy acetylowe z reszt $\mathrm{K} \mathrm{w} \mathrm{N}$-końcowych fragmentach białek histonowych [71]. Wywołuje to kondensację chromatyny i represję transkrypcji genów. Korepresory powodują przyłączenie wielkocząsteczkowych kompleksów, które również wykazują aktywność HDAC i odpowiadają za wzrost siły oddziaływań białek histonowych z DNA nukleosomów [61].

Związanie liganda indukuje zmiany w obrębie LBD RXR, wpływając na oddziaływanie $z$ partnerem, jak również na wiązanie z HRE. Związanie liganda pozwala na dysocjację kompleksów korepresorów i związanie koaktywatorów (ryc. 3B). Obszar oddziaływania LBD RXR z korepresorami i koaktywatorami częściowo się pokrywa. Zmiany w obrębie helisy $\mathrm{H} 12$ indukowane wiązaniem liganda prowadzą do utworzenia struktury promującej oddziaływania

A
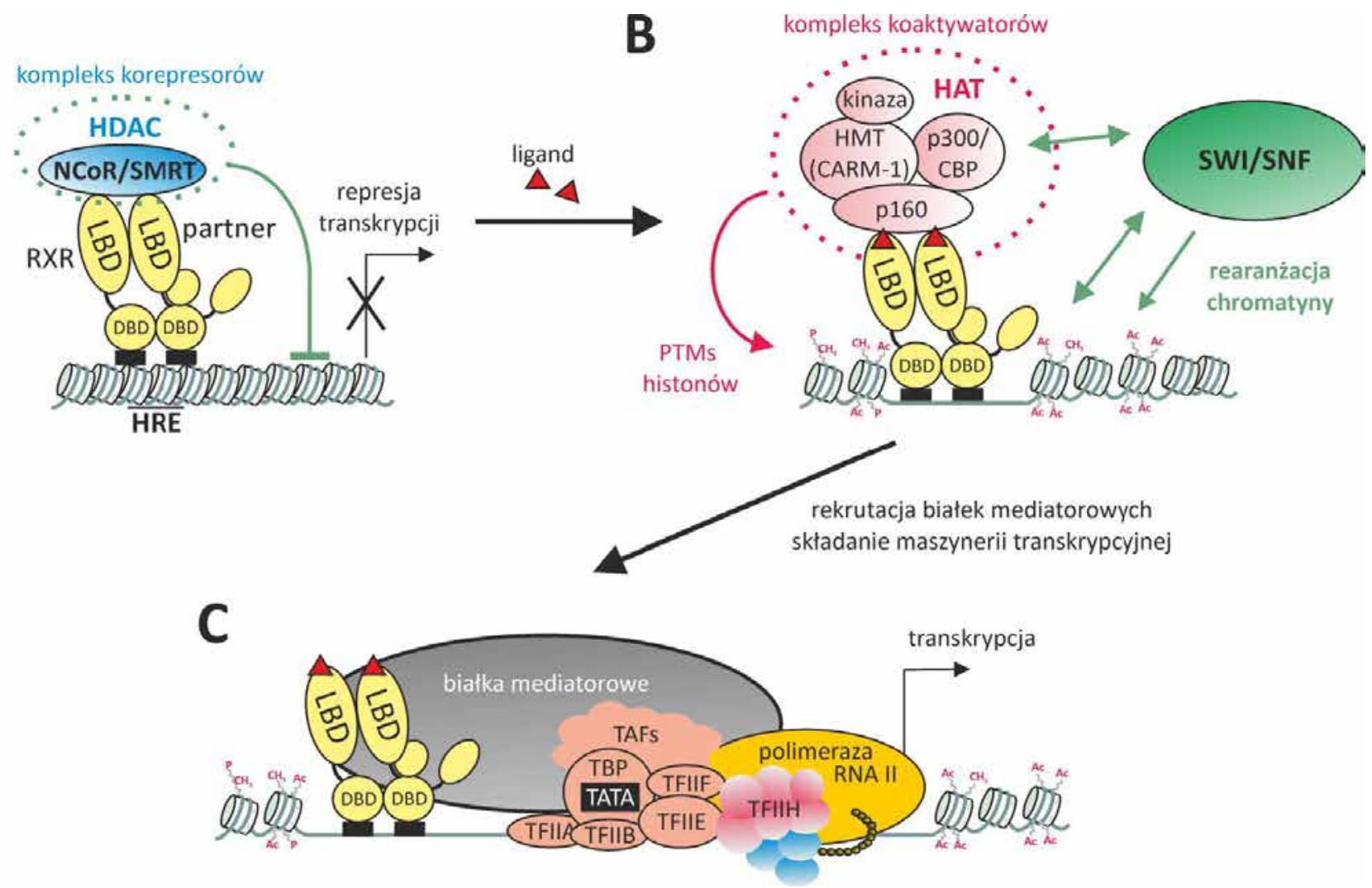

Rycina 3. Trzyetapowy mechanizm aktywacji transkrypcji z udziałem RXR; mechanizm aktywacji transkrypcji z udziałem RXR składa się z trzech etapów: represji (A), derepresji (B) i aktywacji transkrypcji (C). Represja jest zależna od apo-RXR, który oddziałuje z kompleksem korepresorów mających aktywność HDAC. Po związaniu liganda następuje etap derepresji, polegający na oddysocjowaniu kompleksu represorów i związaniu koaktywatorów o aktywność HAT. W trzecim etapie kompleks koaktywatorów oddysocjowuje, a przyłączony zostaje kompleks białek mediatorowych. Umożliwia oddziaływanie z podstawową maszynerią transkrypcyjną i aktywację docelowych genów; wg [50, 72] 
z koaktywatorami. Do koaktywatorów oddziałujących z RXR należy rodzina białek p160, w tym SRC-1, SRC-2 oraz SRC-3 [11]. Zawierają pojedynczy lub obecny w wielu powtórzeniach motyw o sekwencji LXXLL, określany jako kaseta NR (nuclear receptor box) [73]. Jak potwierdziły badania krystalograficzne, motyw LXXLL oddziałuje bezpośrednio ze specyficzną wnęką LBD, która tworzy się w wyniku przemieszczenia helisy H12 pod wpływem związania liganda. Koaktywatory, podobnie jak korepresory, mogą wpływać na strukturę chromatyny. Wykazują aktywność acetylotransferazy histonów (HAT, histone acetyltransferase). Indukowane związaniem liganda werbowanie kompleksu niektórych koaktywatorów przez NRs do rejonów promotorowych powoduje zależną od HAT acetylację histonów, a to obniża powinowactwo histonów do DNA, prowadzi do rozluźnienia struktury chromatyny, ułatwiając dostęp podstawowej maszynerii transkrypcyjnej do rdzenia promotora. Inne koaktywatory, jak np. CARM-1, mają aktywność metylotransferazy histonów (HMT, histone methyltransferase) [11]. Metylacja reszt K i R wpływa na oddziaływanie między histonami a DNA oraz między samymi histonami. Związanie niektórych kompleksów koaktywatorów pozwala na przyłączenie zależnych od ATP czynników rearanżujących chromatynę, jak np. SWI-SNF (switching-defective-sucrose non-fermenting complex). Mimo że rozluźnienie struktury chromatyny jest konieczne, to nie warunkuje inicjacji transkrypcji. Aby umożliwić NRs utworzenie kompleksu preinicjującego (PIC, preinitiation complex), musi dojść do oddysocjowania koaktywatorów i przyłączenia kompleksów pośredniczących (mediator complexes). Kompleks pośredniczący pełni rolę pośrednika między podstawową maszynerią transkrypcyjną i RXR, powoduje bezpośrednie werbowanie polimerazy RNA II wraz z czynnikami transkrypcyjnymi (GTFs, general transcription factors) do rdzenia promotora i do aktywacji transkrypcji (ryc. 3C).

\section{Ligandy}

Związki, które wiąże RXR i które są wstanie go aktywować, należą do różnych grup, wśród nich możemy wyróżnić ligandy naturalne, syntetyczne oraz endogenne [74].

$\mathrm{Na}$ podstawie badań $\mathrm{z}$ lat dziewięćdziesiątych $\mathrm{XX}$ w. powszechnie przyjęto, że endogennym ligandem $R X R$ jest kwas 9-cis-retinowy (9cRA) (ryc. 4), stąd też nazwa tego receptora. Mimo że związek ten in vitro aktywuje zarówno homodimery, jak i heterodimery $R X R$, to jego rola jako endogennego liganda RXR budzi wiele zastrzeżeń. Wykazano, że endogenne stężenie 9cRA jest na poziomie 0,03-0,003 nM [75]. Liczne testy oparte na aktywacji transkrypcji genu reporterowego prowadzone na różnych liniach komórkowych wykazały, że minimalne stężenie 9cRA wymagane do aktywacji transkrypcji mieści się w zakresie 10-100 nM [7]. Oznacza to, że stężenie 9cRA w tkankach jest zbyt niskie, aby związek ten skutecznie mógł wiązać się z receptorem i go aktywować. Jedyne dane wskazujące na znaczenie fizjologiczne 9cRA dotyczą badań na myszach, gdzie w trzustce tych gryzoni potwierdzono obecność 9cRA w stężeniu odpowiednim do wywołania odpowiedzi. Obecnie przyjmuje się, że tylko po suplementacji retinoidami możliwe jest uzyskanie odpowiedniego stężenia 9cRA, aby aktywować RXR. Ze względu na wpływ 9cRA na proliferację i różnicowanie komórek oraz apoptozę, związek ten był badany pod kątem wykorzystania go w chemioprewencji oraz chemioterapii. Alitretynoina ( $9 c \mathrm{RA})$ jest stosowana miejscowo do leczenia uszkodzeń skóry u pacjentów z mięsakiem Kaposiego [76]. Jednak stosowanie alitretynoiny, jak również innych retinoidów, związane jest z licznymi działaniami niepożądanymi takimi jak: bóle głowy, hipertrójglicerydemia, hiperkalcemia czy wysypka; związki te mają silne działanie teratogenne. 9cRA mimo wielu zastrzeżeń związanych z brakiem znaczenia fizjologicznego, stał się wyjściowym elementem do projektowania nowych związków mogących selektywnie aktywować RXR i mieć znaczenie terapeutyczne [62].

Inną grupą związków endogennego pochodzenia, które mogą aktywować RXR, są nienasycone kwasy tłuszczowe (UFAs, unsaturated fatty acids), takie jak: kwas dokozaheksaenowy (DHA), kwas arachidonowy (AA, arachidonic acid) i kwas oleinowy (OA, oleic acid). DHA (ryc. 4) był jednym $z$ pierwszych opisanych aktywatorów RXR [77]. W badaniach porównujących wpływ UFAs na aktywność transkrypcyjną RXR, stężenie DHA wynosiło 5-10 $\mu \mathrm{M}$, a OAiAA wymagały wyższych stężeń rzędu 100-1000 M [78]. Zdolność $\mathrm{RXR}$ do wiązania różnorodnych UFAs podkreśla ważną rolę tego receptora $w$ regulacji metabolizmu komórki. Jednak tak jak w przypadku 9cRA, endogenne stężenia DHA $(0,1-0,01$ $\mu \mathrm{M})$ oraz innych UFAs są niewystarczające do aktywacji transkrypcji z udziałem RXR w warunkach fizjologicznych. Wpływ DHA na aktywność transkrypcyjną RXR została przedstawiona jedynie $w$ badaniach farmakologicznych, które potwierdziły rolę DHA jako liganda RXR i wykazały jego działanie neuroprotekcyjne [79]. DHA powodował wzrost przeżywalności neuronów w liniach komórkowych [80]. Przypuszcza się, że w procesie tym pośredniczy heterodimer RXR-Nurr1. Oprócz właściwości neuroprotekcyjnych, DHA ma ważne znaczenie dla procesów poznawczych, stanów afektywnych i działania antydepresyjnego [81]. Należy zaznaczyć, że sam DHA słabo przenika barierę krew-mózg, a jego metabolity mogą pokonywać ją łatwiej. Nasuwa to wniosek, iż być może to właśnie jeden z metabolitów DHA, a nie sam DHA wiąże się z RXR i wymaga mniejszych stężeń do jego aktywacji [82]. 


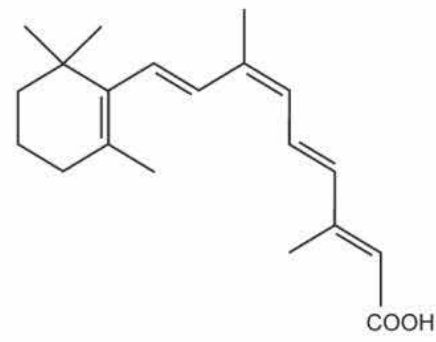

kwas 9-cis retinowy (9cRA)

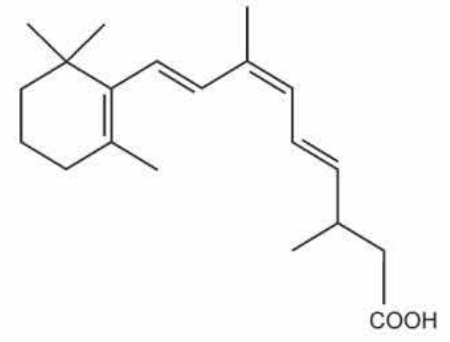

kwas 9-cis-13,14-dihydroretinowy (9cDHRA)

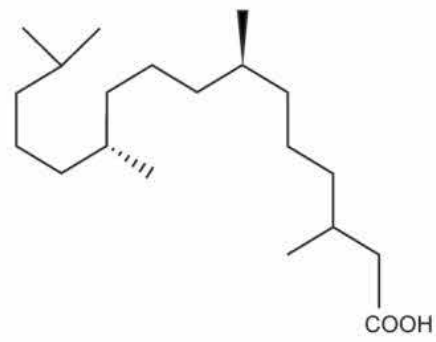

kwas fitanowy

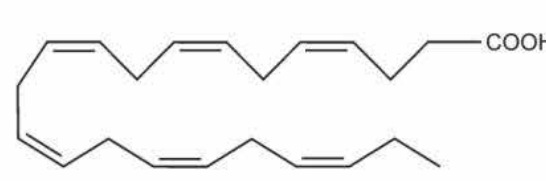

kwas dokozaheksaenowy (DHA)

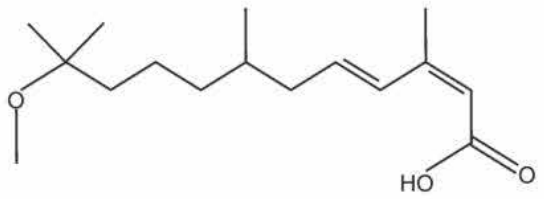

kwas metoprenowy (MPA)

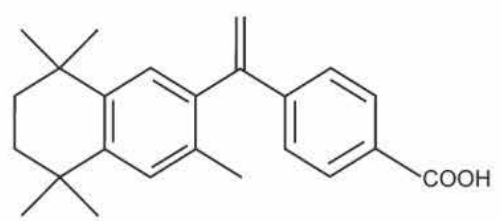

beksaroten

Rycina 4. Wzory strukturalne wybranych ligandów RXR, wg [6, 46]

Związkiem, który rozważano jako naturalny ligand RXR, jest kwas fitanowy (phytanic acid) (ryc. 4). Ten metabolit chlorofilu jest dostarczany do organizmu z pożywieniem; występuje m.in. w mięsie przeżuwaczy i wyrobach mleczarskich. Kwas fitanowy odpowiada głównie za aktywację homodimerów RXR [83], choć może pełnić również rolę liganda PPAR [56]. Kwas fitanowy aktywuje RXR w stężeniu $10 \mu \mathrm{M}$. Jego średnie stężenie w osoczu u ludzi wynosi 1-6 $\mu \mathrm{M}$, a u osób stosujących dietę bogatą $\mathrm{w}$ mięso może być kilkukrotnie większe (około $5,8 \mu \mathrm{M})$. Jednak jest to poziom zbyt niski do aktywacji RXR. Mimo że kwas fitanowy jest ligandem RXR, to jego znaczenie fizjologiczne pozostaje nieznane.

Uwzględniając rolę RXR, jaką pełni w nadrodzinie NRs, identyfikacja specyficznych ligandów dla tego receptora ma podstawowe znaczenie. Wiele związków udało się zidentyfikować jako ligandy RXR, jednak ich stężenie w tkankach było niewystarczające do aktywacji transkrypcji. Obecnie głównym kandydatem do roli endogennego liganda RXR mającego znaczenie fizjologiczne wydaje się kwas 9-cis13,14-dihydroretinowy (9cDHRA) (ryc. 4) [84]. Związek ten wykryto w surowicy ( $400 \mathrm{nM})$, wątrobie ( $450 \mathrm{nM})$ i mózgu ( 130 nM) w stężeniu wystarczającym do aktywacji RXR. Testy aktywacji transkrypcji genu reporterowego prowadzone w komórkach COS-1 wymagały obecności 9cDHRA w stężeniu około $100 \mathrm{nM}$. W badaniach na komórkach dendrytycznych wywodzących się z monocytów (Mo-DCs, human monocytederived dendritic cells) wykazano, że 9cDHRA aktywuje geny będące pod kontrolą heterodimerów LXR/RXR, PPAR/RXR i RAR/RXR. Analiza krystalograficzna wykazała, że 9cDHRA wiąże się w podobny sposób z LBP co 9cRA. Konieczne są dalsze prace mające na celu pełną charakterystykę tego liganda $R X R$.

W życiu codziennym żywe organizmy są narażone na działanie związków, które mogą modulować aktywność RXR, w tym: ftalany, plastyfikatory, niektóre herbicydy, organotyny i farmaceutyki. Jednym $z$ dobrze udokumentowanych związków, będącym ligandem RXR, jest metabolit powszechnie używanego insektycydu - metoprenu, kwas metoprenowy (MPA) (ryc. 4). Związek ten jest analogiem hormonu juwenilnego, który kontroluje u owadów procesy komórkowe związane $\mathrm{z}$ metamorfozą. MPA selektywnie aktywuje RXR, ale nie RAR, działając jako aktywator transkrypcji zarówno w komórkach owadzich, jak i ssaczych [85].

NRs, jako czynniki transkrypcyjne regulowane przez ligand, są celem leków. Ze względu na mnogość genów kontrolowanych przez pojedynczy NR głównym wyzwaniem jest identyfikacja ligandów o działaniu selektywnym względem danego genu lub grupy genów związanych z konkretną chorobą. Istnieje wiele związków syntetycznych zdolnych do oddziaływania $z$ RXR, jednak obecnie dopuszczonych do użytku klinicznego jest tylko kilka z nich. Zostały podzielone na kilka generacji: związki niemające budowy aromatycznej, np. retinoidy naturalne, określa się mianem retinoidów I generacji (np. tretynoina oraz izotretynoina); związki monoaromatyczne - retinoidów II generacji (np. acytretyna), a związki poliaromatyczne zalicza się do retinoidów III generacji (np. adapalen, tazaroten i beksaroten). Retinoidy normalizują wzrost i różnicowanie komórek skóry i błon śluzowych, ponadto działają immunomodulująco oraz przeciwzapalnie. 
Stąd w główniej mierze są stosowane w leczeniu chorób skóry np. łuszczycy lub trądziku. Ze względu na wpływ retinoidów na procesy regulujące podziały komórkowe znalazły zastosowanie w terapii niektórych chorób nowotworowych. Beksaroten (ryc. 4) był pierwszym zatwierdzonym w badaniach klinicznych przez Agencję Żywności i Leków (FDA, Food and Drug Administration) oraz Europejską Agencję Leków (EMA, European Medicines Agency) syntetycznym retinoidem do leczenia chorych z zaawansowanym chłoniakiem skórnym z komórek T (CTCL, cutaneous T-cell lymphoma). Związek ten charakteryzuje się dużym powinowactwem do wszystkich trzech podtypów RXR, ale nie RAR [86]. W ostatniej dekadzie badania kliniczne skupiły się na zastosowaniu beksarotenu w kilku innych nowotworach, m.in. niedrobnokomórkowym raku płuc, ostrej białaczce szpikowej, rakach piersi, tarczycy i czerniaku. W części przypadków zaobserwowano korzyści terapeutyczne. Aktywacja RXR wydaje się zatem mieć duży potencjał terapeutyczny w różnych nowotworach [87]. Oprócz rosnącego znaczenia w nowotworach, ligandy RXR są badane pod kątem wykorzystania ich w chorobach neurodegeneracyjnych, zwłaszcza stwardnieniu rozsianym i chorobie Alzheimera [87]. Wykazano, że beksaroten może odwracać procesy neurodegeneracyjne, poprawiać funkcje poznawcze i zmniejszać poziom $\beta$-amyloidu u transgenicznych myszy [88].

WiększośćligandówRXR nie wykazuje dużejselektywności wobec podtypów/izoform RXR, co jest związane z budową LBP. Wciąż trwają prace nad identyfikacją syntetycznych ligandów RXR mogących selektywnie wiązać dimery RXR (zarówno homodimerów, jak i heterodimerów) i charakteryzujących się mniejszą liczbą działań niepożądanych.

\section{RXR jako potencjalny element wielu terapii}

RXR odpowiada za kontrolę ekspresji wielu genów związanych z utrzymaniem homeostazy organizmu [89]. Receptor ten można uznać za swego rodzaju centralny regulator wielu ścieżek sygnałowych $w$ organizmie. Dzięki zdolności do tworzenia heterodimerów z innymi NRs, RXR może być powiązany z wieloma chorobami. Na szczególną uwagę zasługują: cukrzyca i otyłość, choroby nowotworowe oraz neurodegeneracyjne.

RXR odgrywa bardzo ważną rolę w integracji działania NRs, dla których ligandami są oksysterole (LXR), kwasy żółciowe (FXR) i kwasy tłuszczowe (PPAR) [86]. Jest to grupa należąca do NRs zależnych od liganda RXR, biorąca udział w utrzymaniu homeostazy i metabolizmu energetycznego. Otrzymanie selektywnych ligandów dla takich heterodimerów mogłoby mieć szczególne znacznie w leczeniu zespołu metabolicznego. Wykazano, że inaktywacja RXR w wątrobie myszy jest związana z zaburzeniem licznych szlaków metabolicznych, znajdujących się pod kontrolą heterodimerów RXR [90]. Zauważono również, że zwierzęta leczone retinoidami wykazywały znaczące zmiany w poziomie cholesterolu, związane $z$ hamowaniem jego wchłaniania iobniżoną syntezą kwasówżółciowych. Wregulacji wchłaniania cholesterolu, jego metabolizmie w wątrobie i dystrybucji do tkanek obwodowych biorą udział heterodimery RXR/LXR i RXR/FXR [91]. Aktywacja RXR/FXR hamuje ekspresję hydrolaz CYP7A1 i CYP7B1, które odgrywają istotną rolę w syntezie kwasów żółciowych i wchłanianiu cholesterolu. Natomiast aktywacja RXR/LXR przez retinoidy lub agonistę LXR indukuje zmiany w nabłonku jelita [92]. W enterocytach oraz makrofagach zwiększona zostaje ekspresja transportera ABC1 (ATP-binding cassette transporter) odpowiedzialnego za usuwanie cholesterolu z komórek [93].

RXR tworzą dimery również z PPAR, które pełnią ważną rolę w kontroli metabolizmu kwasów tłuszczowych i utrzymaniu homeostazy glukozowej [72]. Kompleksy RXR/PPAR mogą być aktywowane przez ligandy obu partnerów, jednak mechanizm ich działania jest odmienny. Glitazony (np. pioglitazon i rosiglitazon) należące do grupy tiazolidydendionów (TZDs), znalazły zastosowanie jako leki zwiększające wrażliwość na insulinę. Ich mechanizm działania polega na aktywacji PPARy, co prowadzi do zmiany ekspresji genów, których produkty są związane z transportem glukozy - zwiększa się wychwyt glukozy przez komórki, zmniejsza glukoneogeneza w wątrobie, natomiast zwiększa glikoliza [94]. Ponieważ RXR jest partnerem PPARy, zasugerowano, że retinoidy mogą, podobnie jak TZDs, działać uwrażliwiająco na insulinę. Wykazano, że ligandy RXR zmniejszają insulinooporność u chorych na cukrzycę i otyłych myszy; o ile TZDs miały największy wpływ na ekspresję genów w tkance tłuszczowej, to podstawowe działanie retinoidów obejmowało zmiany w ekspresji genów w wątrobie i mięśniach szkieletowych [89].

Wśród genów wykazujących wzrost ekspresji w mięśniach szkieletowych pod wpływem ligandów RXR znalazły się gen receptora CD36 (cluster of differentiation 36) i desaturazy stearylo-CoA (SCD, stearoyl-CoA desaturase). Zwiększenie poziomu receptora CD36 w mięśniach szkieletowych u zwierząt leczonych retinoidami ma związek ze zwiększeniem wrażliwości na insulinę. Mechanizm, poprzez który SCD reguluje aktywność szlaku insulinowego, nie jest dokładnie wyjaśniony. SCD reguluje przemianę kwasów tłuszczowych i ich poziom w tkankach, jak również odgrywa ważną rolę w regulacji metabolizmu glukozy w mięśniach szkieletowych. Dobrzyn i wsp. [95] wykazali, że SCD ma istotny wpływ na regulację aktywności kinazy białkowej aktywowanej przez AMP (AMPK, AMP-activated protein kinase). Knock out genu kodującego białko SCD w mięśniach szkieletowych myszy, prowadził do aktywacji AMPK przez wzrost poziomu AMP. Podwyższona aktywność AMPK była związana ze 
zwiększonym tempem utleniania kwasów łłuszczowych, a także ze zwiększoną wrażliwością na insulinę [96].

Zidentyfikowano kilka wariantów genów $R X R$, które mogą być związane z zaburzeniami metabolizmu. Polimorfizm genu podtypu $R X R B$ powiązano ze zwiększoną masą ciała oraz ryzykiem wystąpienia kamicy żółciowej [97]. Warianty genu $R X R G$ odpowiadały za podwyższony poziom trójglicerydów, zwiększony poziom cholesterolu LDL oraz cukrzycę typu 2 [98]. Gen RXRG znajduje się na chromosomie w regionie związanym z rodzinną złożoną hiperlipidemią (FCHL, familial combined hyperlipidemia), powszechną postacią dziedzicznej hiperlipidemii [99]. Co istotne, badanie chińskiej populacji pozwoliło na znalezienie kilku polimorfizmów pojedynczego nukleotydu (SNP, single nucleotide polymorphism) dla podtypu $R X R A$, które mogą być odpowiedzialne za zmniejszenie ryzyka zespołu metabolicznego [100]. Jednak funkcjonalne znaczenie tych polimorfizmów wymaga dalszych badań.

Oprócz funkcji związanych z regulacją metabolizmu, RXR jest również zaangażowany $w$ liczne ścieżki sygnałowe centralnego układu nerwowego (CNS, central nervous system). We wczesnym stadium rozwoju ssaków heterodimery RAR/RXR zaangażowane są $w$ indukcję różnicowania neuronów, prawidłowy rozwój CNS, stymulację wzrostu aksonów, a w późniejszym etapie biorą udział w zachowywaniu plastyczności neuronów w hipokampie i układzie węchowym [101]. Wykazano, że RARß oraz RXRY wpływają na plastyczność synaps w hipokampie i przez to na funkcje kognitywne [102]. Głównym podtypem RXR związanym z prawidłowym funkcjonowaniem układu nerwowego jest RXRY. Podtyp ten ulega ekspresji na wysokim poziomie w prążkowiu (striatum), gdzie odgrywa ważną rolę w regulacji dopaminergicznej ścieżki sygnałowej, aktywności ruchowej za pośrednictwem dopaminy i w ośrodku nagrody [55]. RXRy jest również zaangażowany w proces oligodendrogenezy oraz remielinacji, odgrywając rolę pozytywnego regulatora tych procesów. Jego aktywacja stymuluje różnicowanie komórek oligodendrocytów przez nasilenie remielinacji [103]. RXRY ulega ekspresji na niskim poziomie w komórkach glejowych, lecz jego poziom gwałtownie wzrasta u aktywnych makrofagów, reaktywnych astrocytów i dendrocytów w następstwie uszkodzenia CNS [81, 100]. Wykazano także zwiększony poziom RXRY w miejscach demielinizacji oraz zmian patologicznych przy stwardnieniu rozsianym, co może sugerować, że wysoki poziom ekspresji receptora jest fizjologicznym sygnałem uszkodzenia mózgu [103].

RXR działa jako główny koordynator w szlakach przekazywania sygnałów z udziałem NRs, które są zaangażowane w kontrolę wzrostu komórek i różnicowanie [35]. Jak opisano wcześniej, ligandy RXR wykazują obiecujące działania chemioprewencyjne i chemioterapeutyczne w kilku badanych typach nowotworów. Zaobserwowano również, iż rzadko dochodzi do utraty ekspresji RXR w komórkach nowotworowych. Jednak mechanizm działania przeciwnowotworowego RXR i jego ligandów nie jest dokładnie poznany. Jednym z kluczowych aspektów regulacji aktywności NRs jest ich dystrybucja wewnątrzkomórkowa. Głównym miejscem funkcjonowania RXR jest jądro komórkowe. Zaobserwowano, że w ludzkiej linii komórkowej raka piersi (MDA-MB-231) lokalizacja RXRa uległa zmianie, podczas gdy poziom ekspresji RXR pozostał niezmieniony [104]. RXRa rozmieszczony był głównie w SFCs (splicing factor compartments), a nie w sposób równomierny w nukleoplazmie. Następstwem tego było zahamowanie aktywności transkrypcyjnej samego receptora, jak również jego heterodimerów.

Zmiany w poziomie ekspresji RXR są stwierdzane w różnych typach nowotworów. Liczne badania wskazują na obniżenie poziomu RXR w wielu nowotworach, takich jak rak prostaty [105], piersi [106], wątroby [107] czy tarczycy [108]. Natomiast w komórkach ludzkiego raka dróg żółciowych (cholangiocarcinoma) poziom RXR był podwyższony [109]. RXR wykazywał umiejscowienie głównie cytoplazmatyczne, a nie jądrowe jak w zdrowych komórkach. Obniżenie poziomu RXR prowadziło do zmiany w poziomie ekspresji m.in. czynników promujących mitozę - cyklin D1 i E, białka PCNA (proliferating cell nuclear antigen) i inhibitora kinaz zależnych od cyklin p21. Knockdown RXR odpowiadał za obniżenie poziomu cykliny $\mathrm{D} 1$, co miało związek z hamowaniem szlaku Wnt/ß-katenina. Obserwowano również obniżenie poziomu ekspresji białka PCNA i wzrost ekspresji białka p21, co powodowało zatrzymanie proliferacji komórek nowotworowych.

Oprócz zmian w poziomie ekspresji RXR, również zaburzenie jego funkcji może być wiązane z rozwojem nowotworów. Wykazano, że RXRa oddziałuje z białkiem fuzyjnym PML/RARa i ma to duży wpływ na rozwój ostrej białaczki promielocytowej (APL, acute promyelocytic leukemia) u transgenicznych myszy [110]. Białko PML/RARa jest produktem powstałego w wyniku translokacji $\mathrm{t}(15 ; 17)$ (q22,q21) fuzyjnego genu $P M L / R X R A$, złożonego z genu białaczki promielocytowej (PML, promyelocytic leukemia) oraz genu RARA. Kompleks PML/RARa/RXR wpływa na strukturę chromatyny, hamuje transkrypcję i blokuje różnicowanie komórek. Sumoilacja RXR wzmacnia represję genów istotnych w prawidłowym dojrzewaniu komórek. Onkogenne działanie RXR może zostać zniesione w obecności ligandów $R X R$, które umożliwiają odblokowanie ekspresji genów, a tym samym wykazują duży potencjał w leczeniu APL.

Liczne badania z wykorzystaniem różnych linii komórek nowotworowych, takich jak np. komórki raka wątrobowokomórkowego (HCC, hepatocellular carcinoma), kostniakomięsaka (osteosarcoma) oraz raka prostaty, pozwoliły na zidentyfikowanie w cytoplazmie tych komórek 
skróconej formy $R X R \alpha$ (tRXRa, truncated $R X R \alpha$ ) [111]. Formy tRXRa powstają $w$ wyniku ograniczonej proteolizy receptora pełnej długości (RXR). W procesie tym biorą udział katepsyny L oraz m-kalpainy; miejscem ich działania jest koniec $\mathrm{N} R X R \alpha$. tRXRa wykryto w pierwotnych komórkach nowotworowych, ale nie w komórkach znajdujących się $w$ ich sąsiedztwie czy zdrowych tkankach [112]. tRXRa, ale nie RXR, może pośredniczyć w aktywacji szlaku kinazy 3-fosfatydyloinozytolu i AKT (PI3K/AKT) przez czynnik martwicy nowotworów TNF- $\alpha$ (TNF- $\alpha$, tumor necrosis factor $\alpha$ ), cytokininę związaną $z$ procesem zapalnym [112]. tRXRa w odpowiedzi na działanie TNF- $\alpha$ oddziałuje $z$ jednostką regulatorową PI3K (p85a), co zwiększa aktywność szlaku PI3K/AKT oraz przyczynia się do przeżycia i rozwoju komórek nowotworowych. Ponieważ szlak sygnalizacyjny PI3K/AKT odgrywa istotną rolę $\mathrm{w}$ przeżyciu i proliferacji komórek nowotworowych, są prowadzone intensywne badania nad inhibitorami, które mogłyby znaleźć zastosowanie w terapii antynowotworowej. Jednak strategie terapeutyczne wykorzystujące inhibitory szlaku PI3K/AKT są związane z licznymi działaniami niepożądanymi, charakteryzują się dużą toksycznością i brakiem selektywności. Stąd związki hamujące działanie tRXRa mogą się okazać lepszymi celami terapii ze względu na specyficzność i selektywność względem danego typu nowotworu. Wykazano również, że związanie liganda przez tRXRa może wpływać na szlak zewnątrzpochodny apoptozy komórki nowotworowej [112]. Wiązanie niesteroidowego leku przeciwzapalnego (NSAID, nonsteroidal antiinflammatory drug), sulindaku oraz jego analogów z tRXRa prowadziło do aktywacji kaspazy 8 i apoptozy. Przypuszcza się, że aktywacja apoptozy przez NSAIDs jest związana z hamowaniem szlaku PI3K/AKT promującego przeżycie komórek nowotworowych; sulindak $\mathrm{i}$ jego analogi hamowały wiązanie tRXRa z p85a (PI3K).

RXR jest unikalnym członkiem nadrodziny NRs, a ze względu na wielość funkcji stanowi bardzo dobry cel wielu terapii. Jednak mechanizmy działania, za pomocą których RXR wpływa na metabolizm, układ nerwowy czy rozwój nowotworów, są bardzo złożone i niedokładnie poznane, co utrudnia wykorzystanie potencjału terapeutycznego RXR.

\section{Wykaz skrótów}

9cDHRA - kwas 9-cis-13,14-dihydroretinowy, 9cRA - kwas 9-cis-retinowy, AA - kwas arachidonowy (arachidonic acid), ABC1 - transporter ABC (ATP-binding cassette transporter), AD - domena aktywacyjna TFs (activation domain), AF1, AF2 - fragment receptora jądrowego, posiadający zdolność aktywowania transkrypcji (activation function 1, 2), AMPK - kinaza białkowa aktywowana przez AMP (AMP-activated protein kinase), APL- ostra białaczka promielocytowa (acute promyelocytic leukemia), AR - receptor androgenowy (androgen receptor), CAR - konstytutywny receptor androstanu (constitutive androstane receptor), CD36 receptor CD36 (cluster of differentiation 36), CDKs - kinazy zależne od cyklin (cyclin-dependent kinases), CNS centralny układ nerwowy (central nervous system), CoRNR - kaseta CoRNR (corepressor nuclear receptor box), COUP. TF - sierocy receptor jądrowy kręgowców (chicken ovalbumin upstream promoter transcription factor), CRBPII - białko wiążące retinol (cellular retinol-binding protein II), CTCL chłoniak skórny z komórek T (cutaneous T-cell lymphoma), CTE - tzw. przedłużenie końca C DBD w receptorach jądrowych (C-terminal extension), DAX-1 - sierocy receptor jądrowy (dosage-sensitive sex reversal-adrenal hypoplasia congenita critical region on the $X$ chromosome, gene 1), DBD - domena wiążąca DNA (DNA-binding domain), DHA - kwas dokozaheksaenowy (docosahexaenoic acid), ER - receptor estrogenowy (estrogen receptor), FCHL - rodzinna złożona hiperlipidemia (familial combined hyperlipidemia), FXR receptor jądrowy wiążący pochodne farnezolu (farnesoid $X$ receptor), GR - receptor glukokortykoidowy (glucocorticoid receptor), GRIP-1 - koaktywator pośredniczący w funkcji transaktywacyjnej pełnionej przez receptory jądrowe (GRinteracting protein 1), GTFs - grupa podstawowych czynników transkrypcyjnych (general transcription factors), HAT - białko o aktywności acetylazy histonów (histone acetyltransferase), HCC - rak wątrobowokomórkowy (hepatocellular carcinoma), HDAC - białko o aktywności deacetylazy histonów (histone deacetylase), HMT - białka o aktywności metylotransferazy histonów (histone methyltransferase), HRE - sekwencja regulatorowa warunkująca odpowiedź na hormon (hormonresponse element), IDRs - regiony białek, wykazujące inherentne nieuporządkowanie strukturalne (intrinsically disordered regions), JNKs - kinazy aktywowane stresem (c-Jun N-terminal kinases), LBD - domena wiążąca ligand (ligand-binding domain), LBP - kieszeń wiążąca ligand (ligand binding pocket), LLPS - separacja faz typu cieczciecz (liquid-liquid phase separation), LXR - receptor jądrowy wiążący oksysterole (liver $X$ receptor), MAPK - kinaza aktywowana mitogenami (mitogen-activated protein kinase), MLOs - bezbłonowe organelle (membraneless organelles), Mo-DCs - ludzkie komórki dendrytyczne wywodzące się z monocytów (human monocyte-derived dendritic cells), MPA - kwas metoprenowy (methoprene acid), MR receptor mineralokortykoidowy (mineralocorticoid receptor), NCoR - korepresor receptorów jądrowych (nuclear receptor corepressor), NES - sygnał/sekwencja eksportu jądrowego (nuclear export signal), NGFI-B - receptor indukowany czynnikiem wzrostu komórek nerwowych (nerve growth factor-induced protein B), NLS - sygnał/sekwencja lokalizacji jądrowej (nuclear localization signal), NRs - receptory jądrowe (nuclear receptors), NSAIDs - niesteroidowe leki 
przeciwzapalne (nonsteroidal antiinflammatory drugs), Nurr1 - receptor jądrowy kręgowców (nuclear receptor related 1 protein), OA - kwas oleinowy (oleic acid), PCNA - białko PCNA (proliferating cell nuclear antigen), PIC - kompleks preinicjujący (preinitiation complex), PNR sierocy receptor jądrowy (photoreceptor cell-specific nuclear receptor), PPAR - receptor aktywowany proliferatorami peroksysomów (peroxisome proliferator-activated receptor), PR - receptor progesteronowy (progesterone receptor), PTMs - modyfikacje potranslacyjne (post-translational modifications), PXR - receptor wiążący niektóre pochodne pregnanu (pregnane $\mathrm{X}$ receptor), RAR - receptor kwasu całkowicie-trans retinowego (retinoic acid receptor), $\mathbf{R X R}$ - receptor kwasu 9-cis retinowego (retinoid $X$ receptor), SCD - desaturaza stearylo-CoA (stearoyl-CoA desaturase), SHRs - receptory steroidowe (steroid hormone receptors), SMRT korepresor receptorów jądrowych (silencing mediator of retinoid and thyroid hormone receptors), SNP polimorfizm pojedynczego nukleotydu (single nucleotide polymorphism), SWI-SNF czynniki rearanżujące chromatynę (switchingdefective-sucrose non-fermenting complex), SUMO - peptyd dołączany do białek $w$ ramach potranslacyjnych modyfikacji (small ubiquitin-related modifier 1), SUSP1 - proteaza SUSP1 (SUMO-1-specific protease), TFs - czynniki transkrypcyjne (transcription factors), TNF- $\alpha-$ czynnik martwicy nowotworów (tumor necrosis factor $\alpha$ ), TR - receptor hormonów tarczycy (thyroid hormone receptor), TZDs - tiazolidydendiony (thiazolidinediones), UFAs - nienasycone kwasy tłuszczowe (unsaturated fatty acids), VDR - receptor pochodnej witaminy D - 1,25-dihydroksykalcyferolu (vitamin D receptor)

Jeśli w artykule mowa jest o białku pochodzącym z organizmu konkretnego gatunku, skrót nazwy białka poprzedzono pierwszą literą łacińskiej nazwy rodzajowej właściwego organizmu: $h$ - Homo sapiens (człowiek), $m$ - Mus musculus (mysz domowa).

\section{Konflikt interesów}

Autorzy deklarują brak potencjalnych konfliktów interesów.

\section{Piśmiennictwo}

[1] Sladek F.M.: What are nuclear receptor ligands? Mol. Cell. Endocrinol., 2011; 334: 3-13

[2] Młynarczuk J., Rękawiecki R.: The role of the orphan receptor SF-1 in the development and function of the ovary. Reprod. Biol., 2010; 10: 177-193
[3] Sánchez-Martínez R., Castillo A.I., Steinmeyer A., Aranda A.: The retinoid $X$ receptor ligand restores defective signalling by the vitamin D receptor. EMBO Rep., 2006; 7: 1030-1034

[4] Lefebvre P., Benomar Y., Staels B.: Retinoid X receptors: Common heterodimerization partners with distinct functions. Trends Endocrinol. Metab., 2010; 21: 676-683

[5] Skerrett R., Malm T., Landreth G.: Nuclear receptors in neurodegenerative diseases. Neurobiol. Dis., 2014; 72: 104-116

[6] Mangelsdorf D.J., Ong E.S., Dyck J.A., Evans R.M.: Nuclear receptor that identifies a novel retinoic acid response pathway. Nature, 1990; 345: 224-229

[7] Heyman R.A., Mangelsdorf D.J., Dyck J.A., Stein R.B., Eichele G., Evans R.M., Thaller C.: 9-cis retinoic acid is a high affinity ligand for the retinoid X receptor. Cell, 1992; 68: 397-406

[8] Mangelsdorf D.J., Borgmeyer U., Heyman R.A., Zhou J.Y., Ong E.S., Oro A.E., Kakizuka A., Evans R.M.: Characterization of three RXR genes that mediate the action of 9-cis retinoic acid. Genes Dev., 1992; 6: 329-344

[9] Rowe A.: Retinoid X receptors. Int. J. Biochem. Cell Biol., 1997; 29: $275-278$

[10] Aranda A., Pascual A.: Nuclear hormone receptors and gene expression. Physiol. Rev., 2001; 81: 1269-1304

[11] McKenna N.J., O'Malley B.W.: Combinatorial control of gene expression by nuclear receptors and coregulators. Cell, 2002; 108 : 465-474

[12] Hanish B.J., Hackney Price J.F., Kaneko I., Ma N., van der Vaart A., Wagner C.E., Jurutka P.W., Marshall P.A.: A novel gene expression analytics-based approach to structure aided design of rexinoids for development as next-generation cancer therapeutics. Steroids, 2018; 135: 36-49

[13] Yasmin R., Yeung K.T., Chung R.H., Gaczynska M.E., Osmulski P.A., Noy N.: DNA-looping by RXR tetramers permits transcriptional regulation "at a distance". J. Mol. Biol., 2004; 343: 327-338

[14] Shulman A.I., Larson C., Mangelsdorf D.J., Ranganathan R.: Structural determinants of allosteric ligand activation in RXR heterodimers. Cell, 2004; 116: 417-429

[15] Westin S., Kurokawa R., Nolte R.T., Wisely G.B., Mclnerney E.M., Rose D.W., Milburn M.V., Rosenfeld M.G., Glass C.K.: Interactions controlling the assembly of nuclear-receptor heterodimers and co-activators. Nature, 1998; 395: 199-202

[16] Germain P., Iyer J., Zechel C., Gronemeyer H.: Co-regulator recruitment and the mechanism of retinoic acid receptor synergy. Nature, 2002; 415: 187-192

[17] Zhang X.K., Lehmann J., Hoffmann B., Dawson M.I., Cameron J., Graupner G., Hermann T., Tran P., Pfahl M.: Homodimer formation of retinoid $X$ receptor induced by 9 -cis retinoic acid. Nature, 1992; 358: 587-591

[18] Kersten S., Kelleher D., Chambon P., Gronemeyer H., Noy N.: Retinoid $\mathrm{X}$ receptor alpha forms tetramers in solution. Proc. Natl. Acad. Sci. USA, 1995; 92: 8645-8649

[19] Tanaka T., Suh K.S., Lo A.M., De Luca L.M.: p21WAF1/CIP1 is a common transcriptional target of retinoid receptors: Pleiotropic 
regulatory mechanism through retinoic acid receptor (RAR)/retinoid X receptor (RXR) heterodimer and RXR/RXR homodimer. J. Biol. Chem., 2007; 282: 29987-29997

[20] Núñez V., Alameda D., Rico D., Mota R., Gonzalo P., Cedenilla M., Fischer T., Boscá L., Glass C.K., Arroyo A.G., Ricote M.: Retinoid $X$ receptor alpha controls innate inflammatory responses through the up-regulation of chemokine expression. Proc. Natl. Acad. Sci. USA, 2010; 107: 10626-10631

[21] Chen H., Privalsky M.L.: Cooperative formation of high-order oligomers by retinoid $X$ receptors: An unexpected mode of DNA recognition. Proc. Natl. Acad. Sci. USA, 1995; 92: 422-426

[22] Mark M., Ghyselinck N.B., Chambon P.: Function of retinoid nuclear receptors: Lessons from genetic and pharmacological dissections of the retinoic acid signaling pathway during mouse embryogenesis. Annu. Rev. Pharmacol. Toxicol., 2006; 46: 451-480

[23] Chiang J.Y.: Bile acid regulation of gene expression: Roles of nuclear hormone receptors. Endocr. Rev., 2002; 23: 443-463

[24] Sadasivuni M.K., Reddy B.M., Singh J., Anup M.O., Sunil V., Lakshmi M.N., Yogeshwari S., Chacko S.K., Pooja T.L., Dandu A., Harish C., Gopala A.S., Pratibha S., Naveenkumar B.S., Pallavi P.M. i wsp.: CNX-013-B2, a unique pan tissue acting rexinoid, modulates several nuclear receptors and controls multiple risk factors of the metabolic syndrome without risk of hypertriglyceridemia, hepatomegaly and body weight gain in animal models. Diabetol. Metab. Syndr., 2014; 6: 83

[25] Széles L., Póliska S., Nagy G., Szatmari I., Szanto A., Pap A., Lindstedt M., Santegoets S.J., Rühl R., Dezsö B., Nagy L.: Research resource: Transcriptome profiling of genes regulated by RXR and its permissive and nonpermissive partners in differentiating monocyte-derived dendritic cells. Mol. Endocrinol., 2010; 24: 2218-2231

[26] Kim H.T., Kong G., DeNardo D., Li Y., Uray I., Pal S., Mohsin S., Hilsenbeck S.G., Bissonnette R., Lamph W.W., Johnson K., Brown P.H.: Identification of biomarkers modulated by the rexinoid LGD1069 (Bexarotene) in human breast cells using oligonucleotide arrays. Cancer Res., 2006; 66: 12009-12018

[27] Prüfer K., Barsony J.: Retinoid X receptor dominates the nuclear import and export of the unliganded vitamin $\mathrm{D}$ receptor. Mol. Endocrinol., 2002; 16: 1738-1751

[28] Chambon P.: A decade of molecular biology of retinoic acid receptors. FASEB J., 1996; 10: 940-954

[29] Rochette-Egly C.: Nuclear receptors: Integration of multiple signalling pathways through phosphorylation. Cell. Signal., 2003; 15: 355-366

[30] Wärnmark A., Treuter E., Wright A.P., Gustafsson J.A.: Activation functions 1 and 2 of nuclear receptors: Molecular strategies for transcriptional activation. Mol. Endocrinol., 2003; 17: 1901-1909

[31] Kumar R., Thompson E.B.: Transactivation functions of the Nterminal domains of nuclear hormone receptors: Protein folding and coactivator interactions. Mol. Endocrinol., 2003; 17: 1-10

[32] Fernandez E.J.: Allosteric pathways in nuclear receptors - Potential targets for drug design. Pharmacol. Ther., 2018; 183: 152-159
[33] Andersen R.J., Mawji N.R., Wang J., Wang G., Haile S., Myung J.K., Watt K., Tam T., Yang Y.C., Bañuelos C.A., Williams D.E., McEwan I.J., Wang Y., Sadar M.D.: Regression of castrate-recurrent prostate cancer by a small-molecule inhibitor of the aminoterminus domain of the androgen receptor. Cancer Cell, 2010; 17: 535-546

[34] Anbalagan M., Huderson B., Murphy L., Rowan B.G.: Post-translational modifications of nuclear receptors and human disease. Nucl. Recept. Signal., 2012; 10: e001

[35] Ahuja H.S., Szanto A., Nagy L., Davies P.J.: The retinoid X receptor and its ligands: Versatile regulators of metabolic function, cell differentiation and cell death. J. Biol. Regul. Homeost. Agents, 2003; 17: 29-45

[36] Egea P.F., Mitschler A., Moras D.: Molecular recognition of agonist ligands by RXRs. Mol. Endocrinol., 2002; 16: 987-997

[37] Adam-Stitah S., Penna L., Chambon P., Rochette-Egly C.: Hyperphosphorylation of the retinoid $\mathrm{X}$ receptor a by activated c-Jun NH2-terminal kinases. J. Biol. Chem., 1999; 274: 18932-18941

[38] Bastien J., Adam-Stitah S., Plassat J.L., Chambon P., RochetteEgly C.: The phosphorylation site located in the A region of retinoic $X$ receptor $\alpha$ is required for the antiproliferative effect of retinoic acid (RA) and the activation of RA target genes in F9 cells. J. Biol. Chem., 2002; 277: 28683-28689

[39] Choi S.J., Chung S.S., Rho E.J., Lee H.W., Lee M.H., Choi H.S., Seol J.H., Baek S.H., Bang O.S., Chung C.H.: Negative modulation of RXRa transcriptional activity by small ubiquitin-related modifier (SUMO) modification and its reversal by SUMO-specific protease SUSP1. J. Biol. Chem., 2006; 281: 30669-30677

[40] Sołtys K., Ożyhar A.: Ordered structure-forming properties of the intrinsically disordered $A B$ region of $h R X R Y$ and its ability to promote liquid-liquid phase separation. J. Steroid Biochem. Mol. Biol., 2020; 198: 105571

[41] Alberti S., Gladfelter A., Mittag T.: Considerations and challenges in studying liquid-liquid phase separation and biomolecular condensates. Cell, 2019; 176: 419-434

[42] Alberti S., Dormann D.: Liquid-liquid phase separation in disease. Annu. Rev. Genet., 2019; 53: 171-194

[43] Patel A., Lee H.O., Jawerth L., Maharana S., Jahnel M., Hein M.Y., Stoynov S., Mahamid J., Saha S., Franzmann T.M., Pozniakovski A., Poser I., Maghelli N., Royer L.A., Weigert M. i wsp.: A liquid-to-solid phase transition of the ALS protein FUS accelerated by disease mutation. Cell, 2015; 162: 1066-1077

[44] Boija A., Klein I.A., Sabari B.R., Dall'Agnese A., Coffey E.L., Zamudio A.V., Li C.H., Shrinivas K., Manteiga J.C., Hannett N.M., Abraham B.J., Afeyan L.K., Guo Y.E., Rimel J.K., Fant C.B. i wsp.: Transcription factors activate genes through the phase-separation capacity of their activation domains. Cell, 2018; 175: 1842-1855. e16

[45] Kumar R., Johnson B.H., Thompson E.B.: Overview of the structural basis for transcription regulation by nuclear hormone receptors. Essays Biochem., 2004; 40: 27-39 
[46] Gronemeyer H., Miturski R.: Molecular mechanisms of retinoid action. Cell. Mol. Biol. Lett., 2001; 6: 3-52

[47] Wilson T.E., Paulsen R.E., Padgett K.A., Milbrandt J.: Participation of non-zinc finger residues in DNA binding by two nuclear orphan receptors. Science, 1992; 256: 107-110

[48] Zechel C., Shen X.Q., Chambon P., Gronemeyer H.: Dimerization interfaces formed between the DNA binding domains determine the cooperative binding of RXR/RAR and RXR/TR heterodimers to DR5 and DR4 elements. EMBO J., 1994; 13: 1414-1424

[49] Zechel C., Shen X.Q., Chen J.Y., Chen Z.P., Chambon P., Gronemeyer $\mathrm{H}$.: The dimerization interfaces formed between the DNA binding domains of RXR, RAR and TR determine the binding specificity and polarity of the full-length receptors to direct repeats. EMBO J., 1994; 13: 1425-1433

[50] Black B.E., Holaska J.M., Rastinejad F., Paschal B.M.: DNA binding domains in diverse nuclear receptors function as nuclear export signals. Curr. Biol., 2001; 11: 1749-1758

[51] Jacobs C.M., Paulsen R.E.: Crosstalk between ERK2 and RXR regulates nuclear import of transcription factor NGFI-B. Biochem. Biophys. Res. Commun., 2005; 336: 646-652

[52] Dash A.K., Yende A.S., Jaiswal B., Tyagi R.K.: Heterodimerization of retinoid $X$ receptor with xenobiotic receptor partners occurs in the cytoplasmic compartment: Mechanistic insights of events in living cells. Exp. Cell Res., 2017; 360: 337-346

[53] García P., Lorenzo P., de Lera A.R.: Natural ligands of RXR receptors. In: Retinoid Signaling Pathways, ed.: E. Pohl. Academic Press, Cambridge MA 2020, 209-234

[54] Hsieh J.C., Whitfield G.K., Jurutka P.W., Haussler C.A., Thatcher M.L., Thompson P.D., Dang H.T., Galligan M.A., Oza A.K., Haussler M.R.: Two basic amino acids C-terminal of the proximal box specify functional binding of the vitamin $\mathrm{D}$ receptor to its rat osteocalcin deoxyribonucleic acid-responsive element. Endocrinology, 2003; 144: 5065-5080

[55] Kovalevich J., Yen W., Ozdemir A., Langford D.: Cocaine induces nuclear export and degradation of neuronal retinoid $X$ receptor- $y$ via a TNF- $\alpha / J N K-$ mediated mechanism. J. neuroimmune Pharmacol., 2015; 10: 55-73

[56] Zomer A.W., van Der Burg B., Jansen G.A., Wanders R.J., PollThe B.T., van Der Saag P.T.: Pristanic acid and phytanic acid: Naturally occurring ligands for the nuclear receptor peroxisome proliferator-activated receptor $\alpha$. J. Lipid Res., 2000; 41: 18011807

[57] de Lera Á.R., Krezel W., Rühl R.: An endogenous mammalian retinoid $X$ receptor ligand, at last! ChemMedChem, 2016; 11: 1027-1037

[58] Laudet V., Gronemeyer H.: The Nuclear Receptor FactsBook. Academic Press, Cambridge MA 2002

[59] Bruck N., Bastien J., Bour G., Tarrade A., Plassat J.L., Bauer A., Adam-Stitah S., Rochette-Egly C.: Phosphorylation of the retinoid $X$ receptor at the omega loop, modulates the expression of retinoic-acid-target genes with a promoter context specificity. Cell. Signal., 2005; 17: 1229-1239
[60] Germain P., Chambon P., Eichele G., Evans R.M., Lazar M.A., Leid M., De Lera A.R., Lotan R., Mangelsdorf D.J., Gronemeyer $\mathrm{H}$.: International Union of Pharmacology. LXIII. Retinoid X receptors. Pharmacol. Rev., 2006; 58: 760-772

[61] Bastien J., Rochette-Egly C.: Nuclear retinoid receptors and the transcription of retinoid-target genes. Gene, 2004; 328: 1-16

[62] de Almeida N.R., Conda-Sheridan M.: A review of the molecular design and biological activities of RXR agonists. Med. Res. Rev., 2019; 39: 1372-1397

[63] Kojetin D.J., Matta-Camacho E., Hughes T.S., Srinivasan S., Nwachukwu J.C., Cavett V., Nowak J., Chalmers M.J., Marciano D.P., Kamenecka T.M., Shulman A.I., Rance M., Griffin P.R., Bruning J.B., Nettles K.W.: Structural mechanism for signal transduction in RXR nuclear receptor heterodimers. Nat. Commun., 2015; 6: 8013

[64] Lee H.Y., Suh Y.A., Robinson M.J., Clifford J.L., Hong W.K., Woodgett J.R., Cobb M.H., Mangelsdorf D.J., Kurie J.M.: Stress pathway activation induces phosphorylation of retinoid $X$ receptor. J. Biol. Chem., 2000; 275: 32193-32199

[65] Cao X., Liu W., Lin F., Li H., Kolluri S.K., Lin B., Han Y.H., Dawson M.I., Zhang X.K.: Retinoid X receptor regulates Nur77/TR3dependent apoptosis [corrected] by modulating its nuclear export and mitochondrial targeting. Mol. Cell. Biol., 2004; 24: 9705-9725

[66] Matsushima-Nishiwaki R., Okuno M., Adachi S., Sano T., Akita K., Moriwaki H., Friedman S.L., Kojima S.: Phosphorylation of retinoid $X$ receptor alpha at serine 260 impairs its metabolism and function in human hepatocellular carcinoma. Cancer Res., 2001; 61: 7675-7682

[67] Solomon C., White J.H., Kremer R.: Mitogen-activated protein kinase inhibits 1,25-dihydroxyvitamin $\mathrm{D}_{3}$-dependent signal transduction by phosphorylating human retinoid $X$ receptor $\alpha$. J. Clin. Invest., 1999; 103: 1729-1735

[68] Glass C.K.: Differential recognition of target genes by nuclear receptor monomers, dimers, and heterodimers. Endocr. Rev., 1994; 15: $391-407$

[69] Rosenfeld M.G., Glass C.K.: Coregulator codes of transcriptional regulation by nuclear receptors. J. Biol. Chem., 2001; 276: 3686536868

[70] Perissi V., Staszewski L.M., Mclnerney E.M., Kurokawa R., Krones A., Rose D.W., Lambert M.H., Milburn M.V., Glass C.K., Rosenfeld M.G.: Molecular determinants of nuclear receptor-corepressor interaction. Genes Dev., 1999; 13: 3198-3208

[71] Wolffe A.P., Pruss D.: Targeting chromatin disruption: Transcription regulators that acetylate histones. Cell, 1996; 84: 817-819

[72] Shulman A.I., Mangelsdorf D.J.: Retinoid X receptor heterodimers in the metabolic syndrome. N. Engl. J. Med., 2005; 353: 604-615

[73] Heery D.M., Kalkhoven E., Hoare S., Parker M.G.: A signature motif in transcriptional co-activators mediates binding to nuclear receptors. Nature, 1997; 387: 733-736

[74] Krężel W., Rühl R., de Lera A.R.: Alternative retinoid X receptor (RXR) ligands. Mol. Cell. Endocrinol., 2019; 491: 110436 
[75] Arnold S.L., Amory J.K., Walsh T.J., Isoherranen N.: A sensitive and specific method for measurement of multiple retinoids in human serum with UHPLC-MS/MS. J. Lipid Res., 2012; 53: 587-598

[76] Cheng C., Michaels J., Scheinfeld N.: Alitretinoin: A comprehensive review. Expert Opin. Investig. Drugs, 2008; 17: 437-443

[77] de Urquiza A.M., Liu S., Sjöberg M., Zetterström R.H., Griffiths W., Sjövall J., Perlmann T.: Docosahexaenoic acid, a ligand for the retinoid X receptor in mouse brain. Science, 2000; 290: 2140-2144

[78] Lengqvist J., Mata De Urquiza A., Bergman A.C., Willson T.M., Sjövall J., Perlmann T., Griffiths W.J.: Polyunsaturated fatty acids including docosahexaenoic and arachidonic acid bind to the retinoid $X$ receptor alpha ligand-binding domain. Mol. Cell. Proteomics, 2004; 3: 692-703

[79] Mic F.A., Molotkov A., Benbrook D.M., Duester G.: Retinoid activation of retinoic acid receptor but not retinoid $X$ receptor is sufficient to rescue lethal defect in retinoic acid synthesis. Proc. Natl. Acad. Sci. USA, 2003; 100: 7135-7140

[80] Wallen-Mackenzie A., Mata de Urquiza A., Petersson S., Rodriguez F.J., Friling S., Wagner J., Ordentlich P., Lengqvist J., Heyman R.A., Arenas E., Perlmann T.: Nurr1-RXR heterodimers mediate RXR ligand-induced signaling in neuronal cells. Genes Dev., 2003; 17: 3036-3047

[81] Wietrzych-Schindler M., Szyszka-Niagolov M., Ohta K., Endo Y., Pérez E., de Lera A.R., Chambon P., Krezel W.: Retinoid X receptor gamma is implicated in docosahexaenoic acid modulation of despair behaviors and working memory in mice. Biol. Psychiatry, 2011; 69: 788-794

[82] Lo Van A., Sakayori N., Hachem M., Belkouch M., Picq M., Lagarde M., Osumi N., Bernoud-Hubac N.: Mechanisms of DHA transport to the brain and potential therapy to neurodegenerative diseases. Biochimie, 2016; 130: 163-167

[83] Lemotte P.K., Keidel S., Apfel C.M.: Phytanic acid is a retinoid X receptor ligand. Eur. J. Biochem., 1996; 236: 328-333

[84] Rühl R., Krzyżosiak A., Niewiadomska-Cimicka A., Rochel N., Széles L., Vaz B., Wietrzych-Schindler M., Álvarez S., Szklenár M., Nagy L., de Lera A.R., Krężel W.: 9-cis-13,14-dihydroretinoic acid is an endogenous retinoid acting as RXR ligand in mice. PLOS Genet., 2015; 11: e1005213

[85] Harmon M.A., Boehm M.F., Heyman R.A., Mangelsdorf D.J.: Activation of mammalian retinoid $X$ receptors by the insect growth regulator methoprene. Proc. Natl. Acad. Sci. USA, 1995; 92: 61576160

[86] Hiebl V., Ladurner A., Latkolik S., Dirsch V.M.: Natural products as modulators of the nuclear receptors and metabolic sensors LXR, FXR and RXR. Biotechnol. Adv., 2018; 36: 1657-1698

[87] Shen D., Yu X., Wu Y., Chen Y., Li G., Cheng F., Xia L.: Emerging roles of bexarotene in the prevention, treatment and anti-drug resistance of cancers. Expert Rev. Anticancer Ther., 2018; 18: 487-499

[88] Tousi B.: The emerging role of bexarotene in the treatment of Alzheimer's disease: Current evidence. Neuropsychiatr. Dis. Treat., 2015; 11: 311-315
[89] Szanto A., Narkar V., Shen Q., Uray I.P., Davies P.J.A., Nagy L.: Retinoid $X$ receptors: X-ploring their (patho)physiological functions. Cell Death Differ., 2004; 11: 126-143

[90] Wan Y.J., An D., Cai Y., Repa J.J., Hung-Po Chen T., Flores M., Postic C., Magnuson M.A., Chen J., Chien K.R., French S., Mangelsdorf D.J., Sucov H.M.: Hepatocyte-specific mutation establishes retinoid $X$ receptor $\alpha$ as a heterodimeric integrator of multiple physiological processes in the liver. Mol. Cell. Biol., 2000; 20: 4436-4444

[91] Lu T.T., Repa J.J., Mangelsdorf D.J.: Orphan nuclear receptors as eLiXiRs and FiXeRs of sterol metabolism. J. Biol. Chem., 2001; 276: 37735-37738

[92] Lu T.T., Makishima M., Repa J.J., Schoonjans K., Kerr T.A., Auwerx J., Mangelsdorf D.J.: Molecular basis for feedback regulation of bile acid synthesis by nuclear receptors. Mol. Cell, 2000; 6: $507-515$

[93] Repa J.J., Turley S.D., Lobaccaro J.A., Medina J., Li L., Lustig K., Shan B., Heyman R.A., Dietschy J.M., Mangelsdorf D.J.: Regulation of absorption and $A B C 1$-mediated efflux of cholesterol by RXR heterodimers. Science, 2000; 289: 1524-1529

[94] Picard F., Auwerx J.: PPARy and glucose homeostasis. Annu. Rev. Nutr., 2002; 22: 167-197

[95] Dobrzyn P., Dobrzyn A., Miyazaki M., Cohen P., Asilmaz E., Hardie D.G., Friedman J.M., Ntambi J.M.: Stearoyl-CoA desaturase 1 deficiency increases fatty acid oxidation by activating AMP-activated protein kinase in liver. Proc. Natl. Acad. Sci. USA, 2004; 101: $6409-6414$

[96] Dziewulska A., Dobosz A.M., Dobrzyn A., Smolinska A., Kolczynska K., Ntambi J.M., Dobrzyn P.: SCD1 regulates the AMPK/ SIRT1 pathway and histone acetylation through changes in adenine nucleotide metabolism in skeletal muscle. J. Cell. Physiol., 2020; 235: 1129-1140

[97] Chang S.C., Rashid A., Gao Y.T., Andreotti G., Shen M.C., Wang B.S., Han T.Q., Zhang B.H., Sakoda L.C., Leitzmann M.F., Chen B.E., Rosenberg P.S., Chen J., Chanock S.J., Hsing A.W.: Polymorphism of genes related to insulin sensitivity and the risk of biliary tract cancer and biliary stone: A population-based case-control study in Shanghai, China. Carcinogenesis, 2008; 29: 944-948

[98] Wang H., Chu W., Hemphill C., Hasstedt S.J., Elbein S.C.: Mutation screening and association of human retinoid $X$ receptor $Y$ variation with lipid levels in familial type 2 diabetes. Mol. Genet. Metab., 2002; 76: 14-22

[99] Nohara A., Kawashiri M.A., Claudel T., Mizuno M., Tsuchida M., Takata M., Katsuda S., Miwa K., Inazu A., Kuipers F., Kobayashi J., Koizumi J., Yamagishi M., Mabuchi H.: High frequency of a retinoid $\mathrm{X}$ receptor $\mathrm{Y}$ gene variant in familial combined hyperlipidemia that associates with atherogenic dyslipidemia. Arterioscler. Thromb. Vasc. Biol., 2007; 27: 923-928

[100] Shi H., Yu X., Li Q., Ye X., Gao Y., Ma J., Cheng J., Lu Y., Du W., Du J., Ye Q., Zhao X., Zhou L.: Association between PPAR-Y and RXR-a gene polymorphism and metabolic syndrome risk: 
A case-control study of a Chinese Han population. Arch. Med. Res., 2012; 43: 233-242

[101] Baldassarro V.A., Krężel W., Fernández M., Schuhbaur B., Giardino L., Calzà L.: The role of nuclear receptors in the differentiation of oligodendrocyte precursor cells derived from fetal and adult neural stem cells. Stem Cell Res., 2019; 37: 101443

[102] Chiang M.Y., Misner D., Kempermann G., Schikorski T., Giguère V., Sucov H.M., Gage F.H., Stevens C.F., Evans R.M.: An essential role for retinoid receptors RAR $\beta$ and RXRY in longterm potentiation and depression. Neuron, 1998; 21: 1353-1361

[103] Huang J.K., Jarjour A.A., Nait Oumesmar B., Kerninon C., Williams A., Krezel W., Kagechika H., Bauer J., Zhao C., Baron-Van Evercooren A., Chambon P., Ffrench-Constant C., Franklin R.J.: Retinoid $\mathrm{X}$ receptor gamma signaling accelerates CNS remyelination. Nat. Neurosci., 2011; 14: 45-53

[104] Tanaka T., Dancheck B.L., Trifiletti L.C., Birnkrant R.E., Taylor B.J., Garfield S.H., Thorgeirsson U., De Luca L.M.: Altered localization of retinoid $X$ receptor a coincides with loss of retinoid responsiveness in human breast cancer MDA-MB-231 cells. Mol. Cell. Biol., 2004; 24: 3972-3982

[105] Zhong C., Yang S., Huang J., Cohen M.B., Roy-Burman P.: Aberration in the expression of the retinoid receptor, RXRa, in prostate cancer. Cancer Biol. Ther., 2003; 2: 179-184

[106] Crowe D.L., Chandraratna R.A.: A retinoid X receptor (RXR)selective retinoid reveals that RXR- $\alpha$ is potentially a therapeutic target in breast cancer cell lines, and that it potentiates antipro- liferative and apoptotic responses to peroxisome proliferator-activated receptor ligands. Breast Cancer Res., 2004; 6: R546-R555

[107] Ando N., Shimizu M., Okuno M., Matsushima-Nishiwaki R., Tsurumi H., Tanaka T., Moriwaki H.: Expression of retinoid X receptor alpha is decreased in 3'-methyl-4-dimethylaminoazobenzeneinduced hepatocellular carcinoma in rats. Oncol. Rep., 2007; 18: 879-884

[108] Takiyama Y., Miyokawa N., Sugawara A., Kato S., Ito K., Sato K., Oikawa K., Kobayashi H., Kimura S., Tateno M.: Decreased expression of retinoid $\mathrm{X}$ receptor isoforms in human thyroid carcinomas. J. Clin. Endocrinol. Metab., 2004; 89: 5851-5861

[109] Huang G.L., Zhang W., Ren H.Y., Shen X.Y., Chen Q.X., Shen D.Y.: Retinoid $X$ receptor $\alpha$ enhances human cholangiocarcinoma growth through simultaneous activation of $\mathrm{Wnt} / \beta$-catenin and nuclear factor-kB pathways. Cancer Sci., 2015; 106: 1515-1523

[110] Zhu J., Nasr R., Pérès L., Riaucoux-Lormière F., Honoré N., Berthier C., Kamashev D., Zhou J., Vitoux D., Lavau C., de Thé $\mathrm{H} .: \mathrm{RXR}$ is an essential component of the oncogenic PML/RARA complex in vivo. Cancer Cell, 2007; 12: 23-35

[111] Zhang X., Zhou H., Su Y.: Targeting truncated RXRa for cancer therapy. Acta Biochim. Biophys. Sin., 2016; 48: 49-59

[112] Zhou H., Liu W., Su Y., Wei Z., Liu J., Kolluri S.K., Wu H., Cao Y., Chen J., Wu Y., Yan T., Cao X., Gao W., Molotkov A., Jiang F. i wsp.: NSAID sulindac and its analog bind RXR $\alpha$ and inhibit RXRa-dependent AKT signaling. Cancer Cell, 2010; 17: 560-573 